\title{
SOX after Ten Years: A Multidisciplinary Review
}

\section{Citation}

Srinivasan, Suraj, and John C. Coates IV. "SOX after Ten Years: A Multidisciplinary Review." Accounting Horizons (forthcoming).

\section{Permanent link}

http://nrs.harvard.edu/urn-3:HUL.InstRepos:12175242

\section{Terms of Use}

This article was downloaded from Harvard University's DASH repository, and is made available under the terms and conditions applicable to Open Access Policy Articles, as set forth at http:// nrs.harvard.edu/urn-3:HUL.InstRepos:dash.current.terms-of-use\#OAP

\section{Share Your Story}

The Harvard community has made this article openly available.

Please share how this access benefits you. Submit a story.

Accessibility 


\title{
"SOX after Ten Years: A Multidisciplinary Review"
}

\author{
John C. Coates \\ jcoates@law.harvard.edu \\ Professor of Law and Economics \\ Harvard Law School \\ Suraj Srinivasan \\ ssrinivasan@hbs.edu \\ Associate Professor \\ Harvard Business School
}

January 12, 2014

\section{Forthcoming in Accounting Horizons}

\begin{abstract}
We review and assess research findings from $120+$ papers in accounting, finance, and law to evaluate the impact of the Sarbanes-Oxley Act. We describe significant developments in how the Act was implemented and find that despite severe criticism, the Act and institutions it created have survived almost intact since enactment. We report survey findings from informed parties that suggest that the Act has produced financial reporting benefits. While the direct costs of the Act were substantial and fell disproportionately on smaller companies, costs have fallen over time and in response to changes in its implementation. Research about indirect costs such as loss of risk taking in the U.S. is inconclusive. The evidence for and social welfare implications of claimed effects such as fewer IPOs or loss of foreign listings are unclear. Financial reporting quality appears to have gone up after SOX but research on causal attribution is weak. On balance, research on the Act's net social welfare remains inconclusive. We end by outlining challenges facing research in this area, and propose an agenda for better modeling costs and benefits of financial regulation.
\end{abstract}

We thank participants at the Harvard Business School Information, Markets, and Organizations Conference, workshop participants from the HBS Finance unit, Jeffrey Burks, James Cox, Peter Iliev, Michael Klausner, Clive Lennox, Lynn Paine, Krishna Palepu, Shivaram Rajgopal, Eugene Soltes, Urska Velikonja, Paul Zarowin for their valuable comments and to Paul Griffin, Editor of Accounting Horizons, for encouraging us to write this paper. 


\section{INTRODUCTION}

In this article we review and assess over 120 studies of the Sarbanes-Oxley Act, focusing on research in accounting, law, and finance after 2005. We describe major developments in its legal, regulatory and institutional implementation (Part 1) and its effects on US corporate law, disclosure practices, and other countries' laws (Part 2), and the propensity of companies to go or remain public in the US (Part 3). We also note a puzzle regarding the Act's reception in public debate. On the one hand, the law continues to be fiercely and relentlessly attacked in the US, particularly in political election battles and during legislative debates, reflected in part in provisions of the DoddFrank Act and the JOBS Act, which can be seen as a partial legislative rollback of the Act. On the other hand, survey evidence (reviewed in Part 4) suggests that informed observers, including corporate officers and investors, do not believe that the Act - as implemented, taking into account significant relaxations of its most criticized provision (section 404(b) internal control attestation) - has been a significant problem, and may well have produced net benefits, and the law has been copied at least in part by other countries. What explains this puzzle of continued hostility amid acquiescence or even mild praise by those most directly affected by the Act?

We would have liked to have then evaluated the Act itself, at least provisionally, but as we explain, the state of research is such that - even after ten years - no conclusions can be drawn about the net costs (Part 5) and benefits (Part 6) of the Act, its effects on net shareholder wealth (Part 7), or other research relevant to its assessment (Part 8). We suggest that the puzzle of the Act's reception may be explained in part by the inconclusive state of research on its costs and benefits, and so follows a two-part pattern 
that may be generalized to most types of regulation in the spheres of financial institutions, markets, and corporate governance. First - as with most types of regulation - the Act had clear, non-trivial and quantifiable direct costs. Second, the tasks of estimating either the benefits or the indirect costs of the Act are at least an order of magnitude more difficult than the task of estimating direct costs, and are possibly beyond the present capacity of researchers to achieve with much precision.

Absent research designs adequate to the task of drawing even provisionally reliable causal inferences about the Act's full range of effects, the prior beliefs of researchers about its net benefits - which range from large and positive to large and negative - remain largely unaffected by the research that has been done. Absent scholarly consensus, political entrepreneurs have used clear (if overstated) evidence on direct costs to deride the Act as a symbol of regulatory overreach, despite the view among informed observers that the costs and benefits of the law as implemented have been at worst roughly equivalent and possibly net positive.

The stakes implicit in the ongoing uncertainty about the Sarbanes-Oxley Act are large, with lessons for policy-makers and researchers. In Part 9, we sketch a research agenda in light of our literature review and assessment. For researchers, the challenges are to develop methods that better specify and estimate (or at least bound) the Act's potential benefits, as well as its indirect costs, and we preliminarily suggest ways forward on these tasks. For policy-makers, the challenges are how to better design future regulatory (or de- or re-regulatory) interventions so as to permit more reliable inferences about their effects, to improve the quality of information about whether they have led to net benefits, and to reduce the risk that pure politics, untethered by fact or reason, will 
continue to generate unnecessarily costly oscillation in systemically important laws, regulations and institutions that form the foundations of capitalism. These tasks are all the more important given ongoing efforts to legally mandate quantified cost-benefit analysis of financial regulation, which our findings here suggest remains aspirational, rather than feasible. ${ }^{1}$

\section{Sarbanes-Oxley Act remains largely intact, with significant modifications to section 404's implementation}

The Sarbanes-Oxley Act (SOX or the Act) was intended to improve auditing of US public companies, consistent with the law's official name - the Public Company Accounting Reform and Investor Protection Act of 2002. The Act had two core goals: (a) to create a quasi-public institution to oversee and regulate auditing, the Public Company Accounting Oversight Board (PCAOB), and (b) to enlist auditors more extensively in the enforcement of existing laws against theft and fraud by corporate officers, pursuant to regulations from and enforcement by PCAOB. Reinforcing this core were new rules concerning the relationships between public companies and their auditors.

\subsection{PCAOB is a durable and significant part of the regulatory landscape.}

Prior to SOX, auditors were subject only to state licensing and lightly enforced selfregulation. From 1978, a part-time "Public Oversight Board” oversaw auditors, but was dominated by audit firms and had little authority. Recognizing that Congress was in no position to legislate auditing standards in detail, Congress delegated that task in the Act, not to an existing or new public regulatory body, such as the Securities and Exchange

\footnotetext{
${ }^{1}$ For discussion of cost-benefit analysis and legal efforts to mandate it, see Coates (2014).
} 
Commission (SEC), nor to leave it in private hands of the American Institute of Certified Public Accountants (AICPA), but instead to create a unique new hybrid public/private agency in the form of the PCAOB.

PCAOB is a non-profit private corporation charged with the public function of overseeing auditors of SEC-registered companies with the goals of protecting investors and the public interest in the "preparation of informative, fair and independent audit reports.” PCAOB's main tasks are to register, set standards for, inspect, investigate, and discipline public company audit firms. Two but only two of its five full-time directors are auditors, and all of its directors serve staggered five-year terms after being appointed by the SEC. The SEC must approve the PCAOB's budget and regulations, but PCAOB is empowered to directly tax (formally, impose fees on) public companies and audit firms. As a result, its funding is sheltered from the normal Congressional budget process. As a private organization, PCAOB is exempt from so-called "sunshine" laws and can operate largely without the constant pressure of public scrutiny that applies to the SEC and other public bodies. PCAOB can set and enforce regulations, enjoys broad immunity from private lawsuits, and its communications are sheltered behind a regulatory privilege, making them generally not subject to ordinary discovery in lawsuits against audit firms.

This hybrid public/private structure led to a high-profile lawsuit challenging the PCAOB as unconstitutionally invading the sphere of the executive branch (Free Enterprise Fund et al. v. Public Company Accounting Oversight Board et al.). In 2010, the US Supreme Court largely upheld the agency's design and structure, striking down only a provision of the Act that limited removal of PCAOB directors to situations of misbehavior ("for cause"), increasing the theoretical power of the SEC over the PCAOB. 
A broader effort to overturn SOX altogether in the same lawsuit was turned back, however, and PCAOB is now a durable part of the regulatory landscape, largely intact despite frequent political attacks on SOX itself. ${ }^{2}$ PCAOB has a staff of over 600 and an annual budget of $\$ 180$ million. Its budget has grown significantly since 2002, both absolutely and relative to benchmarks such as the SEC's budget - PCAOB's budget is now roughly one sixth of the SEC's budget, as illustrated in Figure 1 panel A. By contrast, while the SEC received a large boost in its own budget in 2003, partly as a result of SOX, its budget has grown more slowly, roughly one-third the PCAOB growth rate since 2003 (see Figure 1 panel B).

\section{- Insert Figure 1 here -}

\subsection{The audit firm / issuer relationship remains as SOX left it.}

Just as the structure of PCAOB remains largely unchanged since SOX, so too does the shape of another major focus of SOX: the relationships between audit firms and public company issuers. In SOX, as well in contemporaneous changes in stock exchange listing standards (discussed in section 2.1), those relationships were significantly changed. Major changes were made (a) to increase the independence of audit committees of public companies, (b) to transfer control of the audit firm relationship to audit committees (from management and the board as a whole), and (c) to give audit committees plenary authority to hire and pay audit firms and other advisors needed for such committees to conduct their now-statutorily mandated responsibilities. These

\footnotetext{
${ }^{2}$ One minor change in the design of PCAOB was adopted in the Dodd-Frank Act in 2010: the PCAOB was required to create and populate an investor advisory board, similar to (and in fact overlapping in membership with) the SEC's advisory committee, also created by that law. On the advisory board are representatives of large institutional advisors such as CalPERs, TIAA-CREF, Vanguard, and the AFL-CIO; accounting academics; corporate governance professionals; and retired judges and regulatory officials. While the advisory board has no formal power, it represents a direct channel of communication from the investor community to PCAOB, and may further buffer the influence of the audit industry over PCAOB.
} 
changes represented a significant change to basic corporate law and governance, which traditionally had been determined at the state (not federal) level, and which traditionally had given the full board of directors authority to delegate whatever authority over the audit firm relationship as it saw fit (including to management of a public company). In addition, SOX mandated audit partner rotation every five years, and banned many nonaudit services that had formed the backbone of the consulting businesses that each of the large audit firms had developed alongside their traditional audit lines of business.

While SOX prohibited audit firms from providing many (but not all) types of consulting services to their audit clients, just slightly preceding SOX, four of the then Big 5 audit firms spun off their consulting arms into separate entities in 2000 and 2001; Deloitte being the only one to not do so. Despite this drastic change in business models arising from the spin-offs, consulting services still account for a large share of revenues for the big audit firms. Non-audit fees to audit clients as a proportion of total fees fell from almost 51 percent of fees in 2002 to about 21 percent in 2005 and have remained steady at that level since then till recently and were around 22 percent in 2012 (Audit Analytics, 2013). But these services are now largely provided to companies that are not audit clients.

Few changes have been made to the rules governing the relationships between audit firms and public company issuers since SOX. In 2003, the GAO released a study on audit firm rotation (as opposed to audit partner rotation), but little was done to pursue further reform until 2012, when the PCAOB issued a concept release on the topic, prompted in part by proposals by the European Community in December 2011 to require audit firm rotation every six years. The PCAOB release generated 630 public comments, 
and attracted some support in the academic community (e.g., Bazerman and Moore 2011). However, as of this writing, neither the PCAOB nor the SEC has followed up on the idea. On July 8, 2013, the House of Representatives passed H.R. 1564, the "Audit Integrity and Job Protection Act," which would amend SOX to prohibit PCAOB from requiring auditor rotation, but as of this writing, the Senate has not taken up the bill.

\subsection{Internal control attestation (section 404(b)) has been significantly modified in the course of implementation.}

The other core component of SOX - the mandate that public companies obtain audit firm attestation over their internal control (IC) systems - proved to be the most controversial. In general terms, SOX required companies to pay audit firms for what were initially costly, time-consuming, detailed, and what many viewed as unjustified reviews of companies' policies, procedures and technologies for preventing theft and fraud. These requirements produced sufficiently loud, widespread, and sustained complaints that PCAOB made significant changes in how SOX section 404 was implemented. Even there, however, the requirement of attestation remains intact for most public companies, and neither Congress nor PCAOB has adopted major changes to the attestation process since 2007.

Contrary to popular impression, SOX did not mandate any particular change in companies' control systems. In 1977, the Foreign Corrupt Practices Act required public companies to have an IC system that would provide "reasonable assurances" that "transactions are recorded as necessary to permit preparation of financial statements in conformity" with GAAP, and nothing in SOX changed this requirement. Even after 
SOX, a public company can if it chooses adopt any IC system it believes meets that requirement - even one with what its auditors believe are significant weaknesses.

What SOX section 404 did was to force disclosure of IC weaknesses, and then to rely on pressures that flow from such disclosures to cause companies to improve their systems. ${ }^{3}$ Only if market forces or litigation risks are sufficiently powerful do companies actually need to change their behavior, in the form of investments to or fees related to their IC systems. An open question at the time SOX was adopted was the extent to which firms would incur all expenses necessary to avoid negative statements about IC weaknesses, or whether they allow weaknesses to exist and persist, despite possible negative market reactions to the disclosures of those weaknesses required by SOX.

As discussed more in Part 5 below, SOX-mandated disclosures did induce significant direct costs. Partly because of those costs, and the criticism that followed, each of the SEC, PCAOB, and Congress have taken further post-SOX actions in response. The SEC deferred implementation of section 404 for companies with market capitalizations of less than $\$ 75$ million, and extended that deferral several times, until 2010, when Congress made it permanent in the Dodd-Frank Act. In 2006, the SEC adopted a rule permitting firms to defer implementation of section 404 for up to two years after going public, which Congress extended to up to five years in 2012 for all but the largest newly public companies (i.e., those with market capitalizations under $\$ 700$ million and revenues and non-convertible debt under $\$ 1$ billion).

\footnotetext{
${ }^{3}$ SOX section 302 likewise imposes only disclosure obligations on CEOs and CFOs, requiring them to certify that a company's SEC filings do not contain material misstatements or omissions, that the officers have evaluated their companies' control systems, which have been designed to ensure material information is disclosed to the officers, and that they have disclosed to the audit committee all significant deficiencies or material weaknesses in the control system.
} 
For firms subject to section 404, the PCAOB in 2007 adopted Audit Standard 5, which significantly relaxed the attestation requirements from those initially adopted in Audit Standard 2 in 2004. Among other things, the 2007 changes permit a unified audit and attestation process; top-down risk-based approaches that permit audit firms to focus on key control risks; the use of "scaled" approaches to take account of firm or IC system component size; the ability to rely on the work of others in the attestation process, so less expensive employees or third party vendors can directly perform some of the work required; and the replacement of time-consuming and elaborate "walk-throughs" with other methods of testing IC systems.

In a large SEC survey conducted after these changes, most respondents reported these changes had been economically meaningful, reducing costs by $25 \%$ or more per year (SEC 2009). Doogar, Sivadasan, and Solomon (2010) find that relative to the initial AS2 benchmark, AS5 audit fees became lower on average for all clients and better aligned with client fraud risk (i.e., lower for lower fraud risk clients and higher for clients with higher fraud risk). As implemented, then, SOX's requirements of IC disclosures and attestation have been significantly loosened, both as to what companies are covered and to what the Act requires. Any fair assessment of SOX as initially enacted would acknowledge that the possibility of such loosening in response to pushback during implementation was part of Congress's original design, because it gave the PCAOB power to relax its initial requirements precisely in this way. We return to this point in Parts 2.2 and 5, below, as it may partly explain divergent assessments of SOX.

\section{Qualitative evidence of SOX's impacts}


SOX and the rules adopted under it by the SEC and PCAOB have now had ten years to shape behavior. Before we review studies that try to measure SOX's costs and benefits, this section reviews qualitative evidence on some of the specific effects that were predicted as consequences of SOX, including: (a) whether SOX "federalized" corporate law, as commonly asserted by its critics; (b) whether SOX has functioned as a "command and control" law, as many have assumed, or more in the nature of a "comply or explain” disclosure-forcing law, often asserted to be more true of similar laws in other countries; and (c) whether other countries have followed or repudiated the US innovations in SOX. Our general conclusions are that SOX had little impact on the federal/state balance of legal authority over corporations, has functioned to force disclosure, which in turn has combined with market forces to induce significant changes in control systems, and has been partly but not completely copied by other countries.

\subsection{Lack of federalization of corporate law}

One prominent criticism immediately following SOX was that it "federalized" corporate law (e.g., Romano 2005; Butler and Ribstein 2006). Straightforwardly, the law did not do this. Other than through the changes in the audit committee / audit firm relationship discussed above, and a relatively toothless ban on loans to public company executive officers, SOX did little directly to alter "corporate governance" or the state laws and stock exchange listing standards that shape governance practices. While major changes in corporate governance did coincide with SOX, they were the result of changes in listing standards adopted by stock exchanges themselves (see Coates 2007: 109-112) for more discussion). 
However, it remained possible that SOX would have powerful effects on corporate governance in two indirect ways. First, it might pave the way for more Congressional intervention, representing a step on a slippery slope to a series of federal legislative changes to corporate law and governance (e.g., Ribstein and Butler 2006). Second, it might result in changes in state law as a result of shareholders suing under state law but using SOX's requirements as a basis for doing so, with the result that SOX would effectively create new standards of conduct for corporate directors (e.g., Burch 2006; Ferola 2007; Jones 2004).

Ten years later, it is apparent that neither of these possibilities has come about. While the Dodd-Frank Act may represent a modest example of the first possible indirect effect, in that it contained general corporate governance provisions that went beyond the financial industry, those changes are even more modest than those in SOX itself. "Say on pay” is perhaps the most well-known part of Dodd-Frank's corporate governance provisions, but that requirement merely imposes a non-binding shareholder vote on executive compensation, and fewer than two percent of US public companies have experienced a negative vote since its implementation. Other aspects of Dodd-Frank fall squarely into the "comply or explain" category, such as a requirement that public companies disclose whether they have two different individuals serving as chairman of the board and CEO, or are extremely modest in their effects, with its authorization for (but not a requirement that) the SEC to adopt regulations permitting shareholders to nominate one to three directors in the company's proxy statement (allowing economization on costs for nomination of a minority of directors), a step that Kahan and Rock (2011) call "insignificant.” Further, the most significant set of changes to US 
securities laws since SOX can be found not in Dodd-Frank, but in JOBS Act, a 2012 law that mandated the SEC adopt a number of new exemptions from the disclosure and registration requirements of the federal securities laws - precisely in the opposite direction that SOX critics predicted. Indeed, by expanding exemptions for widely traded but unlisted firms, the JOBS Act greatly cut back the scope of SOX's coverage.

Turning to state law, a comprehensive review of all Delaware court decisions ( $\mathrm{n}=1293$ ) in the period 2002 to 2012 shows that only fifteen referred in any way to SOX or its provisions. Of those, not one imposed liability on directors for failing to adhere to standards or live up to obligations created by SOX. In fact, no such decision even allowed such a claim to go to trial. Nor has there been a material change in the formal standards of Delaware case law (for example by tightening the definition of what it means to be an "independent" director, as asserted by Ferola $2007^{4}$ ). Nor is there any evident pattern in outcomes of decisions holding corporate directors personally liable (see Black, Cheffins, and Klausner 2006), or in a significantly higher risk of liability for officers, despite section 302 of the Act (see Vogel 2009). Broad claims that SOX has distorted Delaware case law turn out to be overstated at best. Roe (2009) may be right that the fact or threat of lawmaking by Congress or the SEC influences Delaware judges, but the influences are subtle and hard to see in the case law overall. It may be more accurate to understood both federal and state lawmakers reacting simultaneously to timevarying public pressures and political demand for corporate accountability.

\footnotetext{
${ }^{4}$ Compare In re The Limited, 2002 Del. Ch. LEXIS 28 (Del. Ch. Mar. 27, 2002) and In re J.P. Morgan Chase \& Co. Shareholder Litigation, 906 A.2d 2005 (Del. Ch. 2005) (pre- and post-SOX cases, both citing Aronson v. Lewis, 473 A.2d 805, 814 (Del. 1984), both defining "disinterested and independent” director in nearly identical terms and both finding a director "independent" despite being an executive of company with significant business relations with the director's company).
} 
In sum, whatever the effects of SOX more broadly, it has not had the effect of "federalizing” corporate law to any meaningful extent. Delaware (and other states) laws, together with stock exchange listing standards, remain the core of corporate governance in the US, even for public companies. (We discuss data on SOX's effect on federal securities litigation, as opposed to state corporate litigation, below.)

\subsection{SOX's “comply or explain” features in operation}

Another criticism of SOX was that was excessively "mandatory,” directly requiring changes in business decisions, contrary to the tradition of US federal securities laws' focus on disclosure, which permitted business decisions to be made in light of market forces. As discussed above, in one key respect this criticism of SOX was misguided section 404 of SOX, which requires attestation of IC systems, is effectively a "comply or explain” regime, in that it permits companies to allow IC systems to contain weaknesses, as long as that fact is disclosed as part of their own disclosures (and by the audit firm providing the attestation). Nevertheless, it was possible that market reactions and litigation risks associated with IC system weaknesses would be such that no public company would allow them to persist, once identified by an audit firm (even if company officials disagreed with the audit firm). Indeed, Hammersley et al. (2007) document a market reaction of negative $0.95 \%$ for material weakness disclosures suggesting that the material weakness disclosure reports have value relevant information. Ashbaugh et al. (2009) report a 93 basis point increase in cost of equity around the first disclosure of an IC deficiency. Further, firms that remediate IC deficiencies benefit by a 151-point decrease in cost of equity. Most interestingly, Ashbaugh et al report that firms that firms with characteristics making them appear to be most likely to report IC problems but did 
not report such problems, instead reporting an unqualified SOX 404 audit opinion, experienced a 116 basis point decrease in cost of equity.

However, Johnstone et al. (2011) shows that many US public companies disclose persistent IC weaknesses. In the three years ending 2006, they found 733 US companies disclosed a material weakness. By the end of year one, most (59\%) had remedied the weakness, consistent with market forces and litigation risk pressuring companies to eliminate such weaknesses by incurring IC costs. Even after three years, nearly a third (30\%) continued to disclose the same IC weakness.

Related evidence on this comes from Rice and Weber (2011). They find a significant proportion of firms fail to report material weaknesses when they exist. Only $32.4 \%$ of firms that subsequently made a material restatement previously reported a material weakness. That is, most firms did not report the IC weakness when it existed, instead reporting the weakness after a more serious restatement had occurred. (Not all restatements result from control weaknesses, but material restatements often trigger reevaluation of a firm's control systems by both the firm and its auditors.) This suggests that for a significant number of public companies, SOX's section 404 has functioned at least in part in a "comply or explain" fashion, contrary to strong characterizations of that part of the law as "mandating” corporate governance changes.

Further Rice, Weber, and Wu (2013) show weak incentives for timely reporting of section 404 weaknesses. They find firms that do not report a timely IC weakness and later have a restatement are in fact less likely to have class action lawsuits, SEC sanctions, and management and auditor turnover compared to firms with restatement where the IC weakness had been previously reported. They attribute this result to the 
plausible claims by managers of firms not reporting IC weaknesses that they were unaware of the underlying conditions that led to misstatements compared to cases where the IC weakness had been previously disclosed. This suggests that the SOX 404 in operation may not only permit firms to continue to maintain IC systems with weaknesses, but may even create perverse incentives to hide IC weaknesses until a restatement forces the company to reveal them. Far from being too stringent, section 404 as implemented may be milder than would be ideal for a firm's investors.

\subsection{SOX-like laws in other countries}

A third worry expressed by SOX skeptics was that the US would drive public company listings overseas, to regimes less burdened with regulation. Before we review data on that possible effect in Part 3, it is worth noting that many countries imitated the US in adopting SOX-like statutes or regulations following the market downturn in 2001. (Kim and Lu (2013) provide a comprehensive listing of corporate governance reforms undertaken in 26 advanced and emerging economies.) In 2006, for example, Japan adopted its own so-called "J-SOX" statute, the Financial Instruments and Exchange Law, which contained provisions equivalent to those in both sections 302 and 404 of SOX. In 2006, the European Union, too, adopted an Eighth Directive on securities disclosure, which largely tracked much of the contents of SOX. One nominal difference between the way that the European directive was implemented in member states (such as the UK and the Netherlands) was that officer certifications were required, as under SOX section 302, but audit firm attestations as required in SOX section 404 were not.

More generally, a broader contrast is often asserted between the US "mandatory" regime in SOX and the "comply or explain" regime in the EU, and it is true that most of 
the EU member state implementations include "comply or explain” components. But so too does the US (as discussed in the prior section). The stark contrast often suggested is an overstatement at best.

A more important distinction between the way that SOX was implemented in the US and how its equivalents were implemented elsewhere is that the "comply or explain" component is not well enforced in many non-US regimes. Van de Poel \& Vanstraelen (2011) find, for example, that while firms complying with the Dutch equivalent of SOX section 302 experience fewer abnormal or discretionary accruals in the period 2004-05, non-complying firms' accruals showed no relationship with the extent that they explained why they did not comply, consistent with the "explain" aspects of Dutch law not generating market-relevant information, or exerting a strong degree of pressure on Dutch firms. It would be interesting to apply the same method to US firms reporting persistent IC weaknesses to test whether the combination of US disclosure requirements and US market forces are any more powerful than those in the Netherlands.

Why did other countries adopt SOX-like laws? In the absence of research evidence, one could conjecture that, to an extent, the heightened awareness of corporate frauds revealed in the economic downturn in early 2000s drove adoption of new laws to deter fraud. The governance template provided by SOX made it easier for countries to copy the law. Global transmission of regulatory (or best practice) guidelines has been observed before (e.g. board independence rules) and is an interesting topic that has not received much attention in the accounting, finance or legal literatures.

\section{SOX's effects on going private, going dark, going public, and cross-listings}


Another set of predictions commonly advanced by critics of SOX is that it would increase the marginal cost of being a US-registered public company more than the benefits of that status, causing existing public firms to go private or go dark, and deterring other companies from going public or cross-listing in the US. A substantial number of studies have attempted to test these predictions by looking at firm behavior before and after SOX's passage. The going-dark, going-private and cross-listing studies produce similar results - smaller, less liquid and more fraud-prone firms did indeed exit US stock markets after SOX - but the evidence that SOX reduced the number of IPOs is weak at best, and is offset by evidence that IPO pricing improved. More generally, the design of these studies is such that the relevance of their findings to an assessment of SOX remains unclear, as changes in the number of public companies can only be evaluated together with the propensity of those companies to commit fraud and the costs of such fraud.

\subsection{Going private}

Engel, Hayes and Wang (2007) report the propensity to go private spiked in the 33 months after SOX, relative to the same period prior to SOX (see Figure 2). This effect is concentrated among smaller, less liquid firms with growth prospects that are lower than either prior to SOX or as compared to companies that remain public post-SOX. They report a median market value for firms going private post-SOX of \$23 million, less than half than that of firms going private pre-SOX, and less than one seventh that of their overall CRSP/Compustat sample. Kamar, Karaca-Mandic, and Talley (2009) confirm these findings in a difference-in-difference design, comparing going private deals by US firms with those by foreign firms before and after SOX. They find no increase for US 
firms overall, but do find more going private deals by US firms with market capitalizations under \$30 million.

\section{- $\quad$ Insert Figure 2 here -}

Interestingly, then, the majority of firms going private post-SOX were small enough that they would never have had to comply with SOX section 404, which as noted above did not and continues not to apply to $\$ 75$ million or under firms. Indeed, Gao, Wu and Zimmerman 2009 find evidence that firms took steps to "manage" their market capitalizations to remain below this threshold, and so to remain exempt from section 404 . This calls into question whether going private decisions immediately after SOX by small firms were in fact motivated by SOX. Such transactions may instead have either been a response to contemporaneous changes in the financial and legal environments (including low interest rates and a rise in private equity buyout activity), or a mistaken expectation of how SOX would in fact be implemented over time, or both. Consistent with this possibility is the fact that Leuz (2007) finds that going-private trends in the U.K. were similar to those in the U.S. after SOX.

Bartlett (2006) further shows that going private does not per se exempt issuers from the Act, as such transactions often entail issues of high-yield debt that require continued SEC reporting and SOX-compliance. Empirically there was no post-SOX shift in buyout financing (e.g., towards bank debt) that would have exempted newly private companies from the Act, except among firms under $\sim \$ 220$ million in book value. In fact, buyers of large firms were more reliant after SOX on debt financing that triggers ongoing SOXcompliance even after the target firms have gone private.

\subsection{Going dark}


Similarly, more companies chose to "go dark" (i.e., deregister their common stock and thus suspend their SEC reporting obligations) after SOX (Leuz et al., 2008): 370 from 2002-2004 versus 114 from 1998-2001 (see Figure 2). Leuz et al. are careful to exploit several events in the phase-in and extended exemptions for small firms from section 404, making their findings less likely to have been caused by contemporaneous changes in the legal and financial environment. They find that firms that go dark are smaller, have poorer performance, weaker growth opportunities, and are closer to financial distress, than firms that do not go dark. Leuz et al. (2008) also find that that firms that go dark have weaker accounting quality, larger free cash flow problems, and weaker board governance and outside monitoring. These findings raise the question whether there is a net social cost or benefit from going dark (and similar) transactions, given such characteristics may indicate they pose more fraud risk, even if such transactions were privately optimal for the managers of the firms involved and even if they were in fact caused by SOX.

\subsection{Going public}

Some critics of SOX have also claimed that the costs of SOX, especially the burden of section 404 compliance on small firms, contributed to fewer IPOs in the US in the 2000s (e.g., Mitchell et al. 2011). The drop-off in IPOs is most pronounced for small firms, consistent with a SOX explanation. Bova et al. (2013) document a related finding - US private companies, especially smaller ones, are more likely to be acquired rather 
than raise financing through an IPO, post-SOX, unlike a control sample in the U.K., a result that could also contribute to the IPO drop-off. ${ }^{5}$

Such claims in the period leading up 2012 motivated deferral of IC compliance for "emerging growth firms" in the JOBS Act. However, Gao, Ritter, and Zhu (2013) show that the downward trend in IPOs started well before SOX (see Figure 3, where the drop in small firm IPOs occurred in 2001, before SOX's passage). Gao, et al., also document that despite the SEC revising rules to reduce compliance costs burden on small companies, and then small firms being permanently exempted by Congress in the DoddFrank Act, the number of small IPOs has not increased. Gao et al. (2013) attribute the drop-off in IPOs to the absence of profitable small companies and technological changes that make economics of scope and ability to speed products to markets more important than in the past, giving an advantage to larger firms.

\section{- Insert Figure 3 here -}

While the evidence of SOX's effect on the number of IPOs in the US remains contested, the pricing of the IPOs that did occur after SOX improved. Johnson and Madura (2009) find that first-day returns of IPOs in the US have declined in the US (but not in a matched sample of Canadian IPOs not subject to SOX) - that is, US IPOs have not been as underpriced as similar IPOs had been in the past. In other words, IPO pricing became less uncertain, consistent with issuers incurring lower capital costs as a result. They also find that one-year mean and median returns after post-SOX IPOs ceased to be

\footnotetext{
${ }^{5}$ One can also observe a big spurt in IPOs by smaller firms in the mid to late 1990s. Given the higher rate of failure for small firms in general, one would expect a higher rate of de-listings by smaller firms. This poses a challenge to inferring a SOX effect on the higher rates of going dark and going private transactions post-SOX in the literature discussed in Parts 3.1 and 3.2.
} 
negative, as had characterized the pre-SOX period, which Loughran and Ritter (1995) suggest was caused by a correction of first-day excess returns.

\subsection{Cross-listings}

Concerns have also been expressed about fewer foreign firms choosing to list in the US post-SOX, a concern empirically validated in the data (see Figure 4). Piotroski and Srinivasan (2008) find that fewer foreign firms enter US equity markets post-SOX compared to pre-SOX, and that defecting firms are more likely to list in London. Firms that defect to London are smaller, less profitable, less likely to have a Big-4/5 auditor, and are more likely to be based in developed countries. These firm characteristics are consistent with costs of SOX being higher for smaller companies (as with US firms going dark), while the benefits of a US listing are lesser for firms from developed countries.

\section{- $\quad$ Insert Figure 4 here -}

However, the fewer numbers of listings hide the fact that the firms that choose to list in the US post-SOX are larger, more profitable companies from less developed countries. Piotroski and Srinivasan (2008) attribute this to the greater value from SOX driven control and monitoring in the US for larger firms that increases the benefits of a US listing, consistent with the bonding hypothesis (Coffee 1999). In market capitalization terms, these larger cross-listing firms more than make up for the loss in listings by small firms, resulting in a net gain in market capitalization from foreign listings into the US, post-SOX. Bond market evidence is similar. Fewer foreign firms enter US public bond markets, but those that do also have equity listed in the US, are adopters of International Financial Reporting Standards, and are larger bond issuers (Gao 2011). 
Foreign firms are also materially more likely to delist from US equity markets after SOX (see Figure 4). Again, as with US firms going dark, delisting firms are smaller and have low trading volumes in US exchanges (Marosi and Massoud 2008; Woo 2011). These firms had weaker governance (e.g., less independent boards, higher separation of control and cash flow rights, indicating greater agency problems), and were from countries with weaker investor protections (Hostak et al. 2013). While investors in these firms presumably suffered when the firms deregistered, and managers and controlling shareholders benefited by cutting compliance costs and market scrutiny, the social impact on the US is less clear. Similar to domestic US firms that deregistered, foreign firms that delisted have characteristics that make them more likely to have accounting problems and fraud.

\section{Survey evidence - perceptions of SOX's effects}

Before we turn to "hard" evidence on the costs and benefits of SOX, we review "soft" evidence from surveys of informed participants in the capital markets on the specific effects and the costs and benefits of the law. A survey of 336 chief financial officers of companies considering "going public," conducted in 2003 and published in the Journal of Finance by Brau and Fawcett (2006) showed that neither SOX section 404 nor

SEC disclosure requirements more generally were a "significant concern" for such officers, consistent with the findings of Gao et al. (2013) discussed above.

The SEC conducted a comprehensive survey on the economic effects of section 404 between December 2008 and January 2009, which received responses from 2901 companies representing over half the companies filing Sec 404(b) reports at that time. 
Based on this sample, Alexander et al. (2013) report a causal link between section 404 compliance and improvements in quality of the firms' information environment such as a positive impact on IC structures, quality of financial reporting and firm's ability to prevent and detect fraud. Despite respondents' recognition of specific benefits, only $19 \%$ perceived a net benefit for fiscal years completed after the 2007 reforms, with another $20 \%$ saying the costs and benefits were equivalent.

The number perceiving a net benefit from section 404 rose to $26 \%$ for respondents with fiscal years still in progress at the time of the survey, with another $20 \%$ believing the costs and benefits were equivalent - suggesting a trend towards greater acceptance of section 404 over time. Consistent with these findings and the existence of learning curve under section 404 (see Part 5 below), Alexander et al. (2013) report that the number of years of section 404(b) compliance, SEC's management guidance and PCAOB AS 5 are associated with perceived net benefits.

These findings are also consistent with findings in an interview-based study of corporate directors reported in Cohen et al. (2013). The surveyed directors report that SOX had a positive impact on the empowerment and authority of the audit committee and in the responsibilities and status of internal auditors. Directors cautioned that the benefits were tempered by a possible overreaction to SOX driven by perceived increase litigation risk. They also expressed concern that a compliance focus comes at the cost of appropriate risk management.

More broadly, a survey by the Financial Executives Research Foundation in 2005 (FERF 2005) found that 83\% of large company CFOs agreed that SOX had increased investor confidence, and 33\% agreed it had reduced fraud. In a 2009 survey conducted 
by the SEC (SEC 2009) of 2,907 firms, with a response rate of 35\%, which is high for such a large survey of businesses, $27 \%$ agreed that SOX had enhanced investor confidence, but interestingly, an even higher $40 \%$ agreed that SOX had made the respondents more confident in other companies' financial reporting.

In 2010, a Center for Audit Quality survey ( $\mathrm{n}=1001$ ) (CAQ 2010) of investors reported that 65\% were “concerned" about the permanent exemption of \$75 million and under public companies from SOX section 404, and in a 2012 Protiviti survey of public companies with more than one full year of SEC filings, $50 \%$ believed that SOX's benefits outweighed or were equivalent to its costs, $47 \%$ did not think that small public companies should be exempt from SOX section 404(b), and 62\% did not believe section 404(b) should be eliminated for companies under $\$ 1$ billion in market capitalization.

Finally, the GAO (2013) surveyed 746 public companies with a response rate of $25 \%$, specifically focused on SOX section 404 . On the one hand, the GAO reported that $80 \%$ of all companies viewed auditor attestation under section 404 (b) as "benefiting" the quality of the company's controls, 53\% viewed the requirement as benefiting their company's financial reporting, $46 \%$ viewed their ability to prevent and detect fraud as benefiting from section 404(b), and 52\% reported greater confidence in the financial reports of other section 404(b)-compliant companies. On the other hand, only 30\% reported that section 404(b) raised investor confidence in their own company, and only 16\% believed that section 404(b) increased their company’s ability to raise capital.

In sum, contrary to vehement criticism of SOX in some media reports and analyses by political entrepreneurs (and politically active academics), the reception of SOX among the constituencies most affected by SOX has been far more nuanced, even receptive, 
consistent with Langevoort (2007)'s speculation that market and other incentives would blunt managerial hostility to the Act.

\section{$5 \quad$ Evidence on SOX's costs}

We turn now to "hard" evidence on the costs of SOX. These costs include direct costs, such as expenditures on IC systems or litigation, and indirect costs, such as those that may have arisen from SOX's effects on risk-taking, investments, and other activities. We consider which elements of SOX have contributed to these costs, and assess how well research has been able to attribute the observed effects directly to SOX, as opposed to other changes in the legal, accounting, regulatory and market environment for firms that occurred close in time to SOX.

\subsection{Direct costs from control system expenditures}

The direct costs include expenses for IC testing and reporting and audit fees to attest to IC effectiveness. Such costs clearly increased as a result of SOX, but how much remains unclear. The SEC had estimated a cost of $\$ 91,000$ per filer for internal section 404(a) compliance, but did not have a basis for estimating the costs of auditor attestation under section 404(b) (SEC 2004). ${ }^{6}$ Estimates of direct costs of SOX are largely derived

\footnotetext{
${ }^{6}$ Some have criticized the SEC for supposedly grossly underestimating the costs of SOX section 404 . E.g., Sarbanes-Oxley 404: Will the SEC's and PCAOB's New Standards Lower Compliance Costs for Small Companies?: Hearing Before the H. Comm. on Small Bus., 110th Cong. (2007) (statement of Hal S. Scott, Dir. of Comm. on Capital Mkts. Regulation) ("The agency's estimate is now known to be have been off by a factor of 48."); Statement of Hon. Patrick T. McHenry, in A Balancing Act: Cost, Compliance and Competitiveness after Sarbanes-Oxley, Hearing 109-217 (June 19, 2006) at 2 (same). However, these criticisms mis-describe the SEC's analysis, which estimated the internal cost of producing a control report satisfying section 404(a), and not the external cost of obtaining an attestation from a company's auditors on a company's control report, as required by section 404(b). SEC 2004 at V.B and note 174 ("The estimate does not include the costs of the auditor's attestation report, which many commenters have suggested might be substantial.”) On the latter cost, the SEC simply noted that it did not have adequate information publish an informed estimate.
} 
from surveys, but these surveys do not use the same methods or samples, and rely on subjective and potentially biased assessments by respondents on items such as time spent by management overseeing compliance changes. Despite their uncertainties, such surveys do indicate that SOX's costs were and remain increasing in firm size, but at a decreasing rate, so that larger firms pay less for SOX-related services as a percentage of firm size than do smaller firms (Coates 2007; Cox 2013).

Direct costs have also been steadily falling over time for all firms. Charles River Associates estimated, for example, that Fortune 1000 firms spent $\$ 5.9$ million, on average, to comply with section 404 in the first year of implementation (CRA 2005). By the second year, however, similar surveys estimated total direct costs had fallen by between $15 \%$ and $40 \%$ and varied significantly by size of firm (see Coates 2007:107). Subsequent surveys show further drops of $~ 25 \%$ following the 2007 revisions to section 404's implementation by the PCAOB, with the result that by 2012, firms with less than market capitalization of $\$ 10$ billion were paying an average of $\$ 350,000$ for section 404 attestation, representing $~ 30 \%$ of total audit fees (SEC, 2009; GAO, 2013). The SEC survey sample in Alexander et al. (2013) showed an overall average section 404 compliance expense of $\$ 1.2$ million in the latest fiscal year before the survey (Dec. 2008Jan. 2009) and respondents reported a decline over time in such costs.

For at least four reasons, comparisons of audit fees and/or internal costs before and shortly after SOX are likely to exaggerate SOX's actual long-term direct costs. First, they fail to take into account the fact that audit fees were rising prior to SOX (Asthana, Balsam and Kim 2009), and would likely have continued to rise as a result of the financial failures that led to SOX, so that some costs attributed to section 404 would have 
been incurred without SOX. Second, they fail to reflect the fact that firms were already required prior to SOX to have effective IC systems, as noted above, but many did not, so some costs attributed to SOX should instead be attributed to firms "catching up" on their legal obligations in an environment of increased enforcement. Third, in the immediate post-SOX period companies and audit firms were learning rapidly how to better assess and report on their IC systems, resulting in start-up costs and fixed investments with a long potential payoff period being wrongly identified as recurring annual costs. Fourth, they do not reflect the significant cost-saving revisions to the implementation SOX section 404(b) by PCAOB in 2007, discussed above.

To partly address the first two of these issues, Iliev (2010) provides a nicely designed empirical estimate of direct costs of section 404 implementation using a regression discontinuity design, examining the increase post-SOX in audit fees above and below the “small firm” exemption from section 404 for firms with a market capitalization of $\$ 75$ million or less. He finds that - for small firms just above or below the $\$ 75$ million cutoff, filing a control effectiveness report under section 404(a) in 2004 increased audit fees (due to the attestation requirement in section $404($ b)) by $86 \%$, or roughly $\$ 528,000$ for the mean firm with a market capitalization of $\sim \$ 135$ million. However, as reflected in Figure 5, his findings by design cannot be generalized to the larger firms that are the majority of companies subject to SOX and on which greater SEC scrutiny was brought post-SOX (as discussed below). In addition, his research design does not address the second two issues reviewed above. Survey results from more recent periods are likely a better approximation of long run, equilibrium direct costs of SOX, and, as noted above, on average they are much lower than Iliev's small-firm estimate. 


\section{- Insert Figure 5 about here -}

\subsection{Direct costs from securities litigation related to SOX}

Another type of direct cost predicted to result from SOX is litigation-related costs. Lawsuits brought under US securities laws might have become easier to pursue (or use to extract settlements) as a result of SOX sections 302 and 404, which together force more disclosures that may be used by plaintiffs and their lawyers to identify defendants and to present in court as evidence of fraud. Critics expected that SOX would generate more litigation - indeed, some went so far as to predict an explosion of litigation as a result of SOX, which they called a "litigation time bomb" (Butler \& Ribstein 2006). There was also concern about higher litigation risk for independent directors due to greater responsibilities under SOX especially for audit committee directors (Bebchuk et al 2006).

Securities litigation incidence did rise from 2002 to 2004 following SOX (see Figure 6, Panel A). However, it dropped to pre-SOX levels soon thereafter, with no subsequent change in law that could account for the drop. Similarly, litigation risk for independent directors spiked in 2002, but then reverted to pre-SOX levels. Brochet and Srinivasan (2013) examine litigation risk for independent directors and document no increase over time in such risk (see Figure 6).

\section{- Insert Figure 6 here -}

Settlements amount also increased in the period 2004-2006 (see Figure 6, Panel B). Likely reflecting this proximate trend, director and officer insurance premiums increased substantially. Linck, Netter and Yang (2009) found that median D\&O insurance premiums increased by more than 150\% from 2001 to 2004. However, this evidence is 
restricted to a small sample of firms, since $\mathrm{D} \& \mathrm{O}$ insurance is only required to be reported for firms incorporated in New York state. However, with no change in the underlying law, securities litigation settlements began to plummet in 2007, and have remained steady at relatively low, pre-SOX levels since 2008. This pattern is not consistent with SOX creating a powerful array of litigation tools for shareholders to sue companies or their managers, or for plaintiffs' lawyers to use on behalf of shareholders in class actions.

Instead, the pattern is more consistent with large costs arising from the fundamental corporate misconduct that gave rise to SOX, followed by a reduction in that misconduct (at least as perceived by litigants and other participants in the legal system). This pattern holds even after taking account of three of the largest all-time settlements (Enron, Worldcom, and Tyco). Whatever the costs of SOX, increased litigation does not appear to be one of them.

\subsection{Indirect costs of SOX}

In addition to (and likely more important than) the direct costs discussed above, SOX also imposed indirect costs on firms. While direct costs can be significant, especially for small firms, indirect costs can be large for all firms if managers and boards of directors lowered investments and risk-taking due to fear of the increase in director and officer liability and/or due to distraction from core business concerns by the increased focus on internal controls. Alan Greenspan noted in 2003 that "business leaders have been quite circumspect about embarking on major new investment projects.” (Greenspan 2003) Echoing similar concerns, William Donaldson, former chairman of the SEC predicted that SOX would lead to a "loss of risk-taking zeal" and has created a 
"huge preoccupation with the dangers and risks of making the slightest mistake." (Michaels 2003)

Some studies have attempted to back up these claims with detailed findings. Kang, Liu and Qi (2010) find that the investment to capital ratio declined for US firms compared to a sample of UK firms after 2002. This evidence is corroborated by Bargeron, Lehn and Zutter (2010) who find several measures of risk taking decline for US firms compared to a sample of publicly listed UK and Canadian firms over the period 1994 through 2006. Similar to the trends observed in Figure 7 (from Albuquerque and Zhu, 2013), they find that US firms reduced their investment in capital and R\&D expenditures, increased their cash holdings and reduced leverage over this time period. Standard deviation of stock returns for US firms also fell compared to non-US firms. These changes are greater for larger firms compared to smaller ones.

\section{- $\quad$ Insert Figure 7 here -}

However, as with the decline in US IPOs depicted above, Figure 7 shows that the trends in investments and cash holdings manifested before SOX. In fact, Bates, Kahle and Stulz (2009) document a trend of increasing levels of cash holdings and lower leverage for US firms starting early 1980s. Albuquerque and Zhu (2013) contest the findings of SOX driven lower investments using a regression discontinuity design similar to Iliev (2010). They compare firms that were just above and below the threshold of $\$ 75$ Million in market capitalization for section 404 implementation. They find that investment declines post-SOX for small firms subject to section 404. However, they find a similar decline in investment for the companies not subject to section 404, suggesting 
an overall decline in investment in US companies. As shown in Figure 7, they find that the decline begins in 1999 or even earlier and not in 2003, when SOX went into effect.

In other words, comparisons with the UK and Canada in Kang et al. (2010) and Bargeron et al. (2010) likely capture a trend of declining investment in the US, but one that is unrelated to SOX. Indirect costs remain possible side effects of SOX, but their size and significance remain unclear.

\section{Evidence on SOX’s benefits}

Next we survey the evidence on the benefits of SOX.

\subsection{Impact on accounting quality}

A number of papers provide evidence consistent with the observation that accounting quality improved for US firms in the post-2002 time period. Cohen, Dey, Lys (2008) find that accrual based earnings management increases steadily from 1987 till 2002, then declined significantly. Some part of this decline has been offset by an increase in real earnings management (as measured by abnormal cash from operation, abnormal production costs, and abnormal discretionary expenses), which had been declining prior to SOX. Likewise, firms that just met earnings benchmarks used less accrual and more real earnings management post-SOX compared to similar firms before SOX (Chhaochharia and Grinstein 2007; Lobo and Zhou 2006).

Despite the offset in higher real earnings management, however, other studies suggest a general improvement in accounting quality. Koh, Matsumoto, and Rajgopal (2008) and Bartov and Cohen (2009) find that firms exhibited a lower tendency to engage

in the phenomenon of just meeting or beating analysts' consensus forecasts by managing 
earnings. Lobo and Zhou (2006) document a significant increase in timely loss recognition, a measure of how quickly accounting incorporate economic losses. Daniel, Denis and Naveen (2008) find that firms manage earnings less for dividend payout reasons. Dyck, Morse, and Zingales (2010) find that auditors greatly increased their role in detecting and reporting fraud in public companies after SOX, relative to other sources of fraud detection, from $6 \%$ of total frauds to $24 \%$ in the post-SOX period. This increase is spread across not only restatement cases, but also those not involving restatements. Kedia, Koh, and Rajgopal (2013) find that prior to 2002, companies were more likely to copy poor accounting practices (that lead to a restatement) upon observing restatements by industry peers. This behavior appears to have stopped after 2002, which the authors conjecture is driven by more rigorous enforcement after SOX.

Further, some evidence suggests these improvements may be driven by a combination of SOX and changing behavior in stock markets and inside boardrooms. Brochet (2010) finds that insider trading disclosures became more informative after SOX. CEO and CFO certifications seem to have helped as well. Qian, Strahan and Zhu (2013) find that firms with public floats above the trigger for SOX section 404 (\$75 million) but below \$350 million reduced CEO compensation but increased insider ownership, while firms below $\$ 75$ million increased CEO pay and did not increase insider ownership in the post-SOX period. Stock market premium to meeting analysts' consensus forecasts disappeared post-2002 according to Koh et al. (2008). In fact, post-2002, stock prices react negatively to positive earnings surprises by firms the CEOs of which have higher equity incentives. Similarly, Jiang, Petroni, and Wang (2010) find that CEO equity incentives, considered a culprit in providing perverse earning management incentives to 
managers to artificially boost stock prices, are not related to proxies for earnings management post-SOX in contrast to the pre-SOX time period. They find that neither CEO nor CFO equity incentives are positively related to magnitude of accruals during 2002-2006 period in contrast to the prior period - 1993-2001. In fact, the relationship of accruals to CFO incentives reverses - higher incentives are associated with a lower magnitude of accruals. Boards seem to take the apparently improved managerial behavior into account when setting pay - sensitivity of bonus pay to accounting performance becomes higher as documented in Carter, Lynch, Zechman (2009). They also find that firms place more weight on positive earnings changes post-SOX and that firms with the largest decrease in positive discretionary accruals have the largest increase in weight on earnings changes. Significant increase in sensitivity of CEO cash compensation to accounting performance suggests that boards trust accounting numbers more.

One of the precursors to SOX was the steady rise in restatements prior to 2002. After SOX, the number of restatements initially increased dramatically, the increase is mostly attributed to the increased vigilance post-SOX. The rate of restatements fell as dramatically as they rose (Figure 8, Panel A). On average, restatements have been less egregious after SOX as seen in lower dollar amounts, more unintentional errors, more noncore accounts, and a lower average negative market reaction to restatement announcements after controlling for the lesser intensity (Burks 2010; Burks 2011; Hennes et al. 2008; Plumlee and Yohn 2010; Scholz 2008). Finally, the extent of adverse SOX section 404 auditor attestation opinions (as a fraction of all companies to which section 404 applies) has been declining over time, ranging from a high of 16.9 percent in 2005 when the mandates first kicked in to 2.4 percent in 2010 (see Figure 8, Panel B). 
The main weakness of these streams of research on SOX's benefits (as with studies of SOX's costs, discussed above) is that while the effects documented are for the time period following SOX, the accounting quality benefits found in this literature may not have been caused by SOX itself. Critics can validly claim that several benefits could have arisen from market discipline following a period where internal controls were widely seen to have collapsed. Research designed to isolate the effects of SOX is challenging since the Act affected all large SEC registered firms in the US, depriving researchers of a control group of firms that was unaffected by SOX and yet comparable to the majority of US public companies. Several contemporaneous changes such as changes in stock exchange guidelines provide alternate explanations for the observed effects. Finally, SOX has several complementary provisions making it difficult to identify the provisions that contributed to the changes in observed behavior.

\subsection{Impact of Section 404 disclosures}

Other research more directly documents the benefits of SOX using information in SOX-driven disclosures. IC weakness reports mandated by SOX have proved informative to investors. Firms with IC weaknesses have accruals that do not map well into cash flows, more auditor resignations, more restatements and SEC enforcement actions, provide less precise management forecasts, and CFOs with weaker qualifications (Doyle et al., 2007; Ashbaugh-Skaife et al., 2007; Feng, Li, McVay., 2009; Li, Sun, Ettredge., 2010). Not surprisingly, investors react negatively to disclosure of IC weakness reports increasing both the cost of debt (Kim, Song, and Zhang, 2011) and of equity (Hammersley et al., 2007). Lenders are seen to modify debt contracts to rely less on financial numbers in covenants when firms disclose IC weaknesses and instead substitute 
them with price, security and credit rating based protection (Costello and WittenbergMoerman, 2011). Because such studies link changes in behavior to specific requirements in the Act, they more plausibly reflect causation, rather than temporal correlation, but they also leave a greater gap between the results and a quantitative assessment of the value of the benefits.

While the IC disclosure mandate in section 404 has come in for the most criticism for the costs imposed on companies, better controls have been found to be helpful in improving accounting quality. Using a sample of banks unrelated to SOX, Altamuro and Beatty (2010) find that rules adopted in 1992 requiring internal control reporting for banks led to greater validity of loan loss provisions in banks. The association between loan-loss provisions and actual loans written off strengthened after the law was passed, and IC reporting led to greater earnings persistence, better ability of earnings to predict cash flows, and reduction in use of earnings management to report positive earnings growth but also to lower earnings conservatism. They conclude that banks exercised less reporting discretion after IC reporting was introduced. Not surprisingly, Ashbaugh-Skaife et al. (2008) find that earnings' properties improve after remediation of ineffective internal controls. Remediation involves changes to management and boards and leads to hiring of better-qualified CFOs. (Li, Sun and Ettredge 2010; Johnstone, Li and Rupley 2011). Firms also improve their investment efficiency after remediation of IC weaknesses (Cheng, Dhaliwal, and Zhang 2013).

The implementation schedule of section 404 reporting allowed for studies that can produce more compelling evidence of causal effects, at least over certain subsets of firms. Evidence from such studies reinforces the view that section 404 causally improved 
accounting quality. Iliev (2010) finds that section 404 filers just above the $\$ 75$ million exemption from section 404 had significantly lower accruals and discretionary accruals in 2004 compared to firms just below the implementation threshold, which he interprets as more conservative reporting. Arping and Sautner (2013) find a reduction in analyst forecast error and forecast dispersion for European firms listed in the US and subject to SOX more than for matched foreign firms not cross-listed in the US. These results are driven by the time period when foreign firms were required to comply with provisions of section 404 (after 2006 and not before).

\subsection{Impact of SOX on audit quality}

Accounting quality likely also improved because of improvements in audit quality. DeFond and Lennox (2011) find that, post-SOX, a number of small audit firms exited the market for public company audits. Roughly half (607) of 1233 small audit firms (small firms being defined as those with fewer than 100 SEC clients) exited the public audit market following SOX. Small auditors comprise $97 \%$ of all audit firms and audit 34\% of public companies. Clients move to other smaller auditors - with remaining small auditors doubling their average client base - but compared to the non-exiting auditors, the exiting auditors are lower quality. Clients of exiting auditors receive higher quality auditing from successor auditors, and successor auditors are more likely than exiting auditors to issue going concern opinions to the new clients. The authors conclude that PCAOB inspections under SOX improve audit quality by incentivizing low quality auditors to exit the market. Raghunadan and Rama (2006) document a significant increase (74 to 86 percent) in audit fees after SOX consistent with both a rise in audit effort and increased work load attributable to SOX 404 implementation. Griffin and Lont 
(2007) show that this increase reflected higher audit risk suggesting that SOX increased the auditors share of risk of defective financial statements. (See also Defond and Zhang (2013) for a review of audit research that focuses on SOX.) PCAOB inspections appear to have played a role in improving audit quality. DeFond and Lennox (2011) attribute the exit of smaller and lower quality audit firms to the threat of PCAOB inspections. Abbot, Gunny, and Zhang (2011) find useful information content in PCAOB inspections smaller auditors that receive adverse PCAOB inspection reports have clients with accounting restatements and poor accrual quality. However, inspection reports are not found to lead to auditor switching by clients suggesting that clients do not find the inspection information useful in selecting auditors (Lennox and Pittman 2010). PCAOB sanctions against auditors are seen to be informative to investors and prompt audit firms to improve audit quality. Dee, Lulseged, and Zhang (2011) examine PCAOB's 2007 sanction of Deloitte for an audit failure in 2004 that revealed quality control problems at Deloitte at its local San Diego office as well as nationally. They find that Deloitte clients suffered a negative 0.83 percent three day return surrounding the announcement of the sanction which the authors attribute the quality control problems identified at Deloitte, which undertook governance changes to strengthen oversight of its partners and directors.

\section{$7 \quad$ Event studies of net shareholder wealth effects}

The above combination of evidence on costs and benefits of SOX is hard to bring down to a single bottom line. Some of the direct costs can be reduced to dollars, but there is substantial variation across firms and over time even in those costs. Other direct 
costs, and all of the benefits and indirect costs, are not easily translated into bottom-line dollar costs. As a result, the costs and benefits cannot be totaled into a single net effect.

Partly because of these limitations, some scholars have attempted to use a single method to estimate both costs and benefits. These studies have looked to stock market reactions to critical events in the legislative process leading up to the enactment of SOX and test market reaction around these events. Unfortunately, these studies have proven no more useful in resolving the policy assessment of SOX, producing widely disparate results and remaining subject to significant uncertainties.

On the one hand, Zhang (2007) finds that stock prices decline in response to events leading up to the passage of SOX. Firms with weaker shareholder rights, higher pre-SOX non-audit fees, more extensive foreign operations and larger abnormal accruals experienced greater negative returns. On the other hand, Jain and Rezaee (2006), Li, Pincus, and Rego (2008); Akhigbe and Martin (2006) document that stock prices react favorably to the events leading up to the passage of SOX. Stock prices react favorably for firms with higher levels of pre-SOX governance, those with more reliable accounting, and higher quality audit. There is a positive relationship of returns with extent of earnings management and a positive stock price impact for financial services firms except for securities firms.

Again, the staggered implementation of section 404 provides the best opportunity to find an effect most directly attributable to SOX. Iliev (2010) finds that non-accelerated filers experience positive returns when the section 404 compliance deadline was extended. This implies that investors respond as if the costs outweigh the benefits. While these results are able to capture the net effect of the law, the findings are limited to 
relatively small firms that qualified for the extended compliance deadline, and are not valid as estimate of the overall effect of SOX on public firms generally. In addition, this paper and the other event studies noted above use different sets of events and present different and somewhat subjective interpretations of whether given events improving or reducing the odds of SOX's passage. ${ }^{7}$

Leuz (2007) identifies a number of non-SOX related negative news events on the dates identified in Zhang (2007) (e.g., declaration of Iraq war) that make it hard to identify SOX as the cause of the market reactions studied. More generally, event study methods are better suited for clearly defined events and not events that depend upon the opaque process of legislation. Finally, implementation of SOX took place over time, and (as described above) involved several decisions that were not easily foreseeable at the time of SOX's adoption - including PCAOB's 2007 changes in section 404's implementation and the deferral and eventual exemption of small issuers altogether from section 404 - making it difficult for the market to assess how the changes would unfold.

\section{Other research relevant to evaluating SOX}

\subsection{Ban on consulting services by audit firms}

Accounting literature has consistently diverged from the views of policy makers and found scant evidence that non-audit fees adversely affect financial reporting quality. For example, DeFond et al. (2002), Chung and Kallapur (2003), Ashbaugh et al. (2003),

\footnotetext{
${ }^{7}$ Some papers provide event study evidence on CEO/CFO certification requirement in Section 302 of SOX, again with mixed evidence. Griffin and Lont (2005) find that the certification event is value relevant whereas Bhattacharya, Groznik, and Haslem (2007) find that the certification was a non-event for certifiers around their certification date. Again differing methodologies in these papers do not allow for reconciliation of these results.
} 
Kinney et al. (2004) and Koh et al. (2012) all find no effect of non-audit fees on financial reporting quality). Indeed, by banning such services, SOX has made further study difficult due to the elimination of observed variation in practice.

\subsection{Role of SEC enforcement}

SOX expanded SEC resources and gave the SEC more legal tools, but the political environment as it relates to fraud shifted concurrently with SOX, making it possible that SEC priorities would have shifted without regard to SOX. ${ }^{8}$ Descriptive evidence suggests that the SEC brought more accounting and auditing enforcement cases and pursued larger companies in the aftermath of the scandals in 2002, which was no doubt supported by the increased budget (see Table 1). The median size of company that is the subject of an accounting and auditing enforcement release (AAER) shows a clear upward movement from the pre-2002 to the post-2004 time period. Note that Table 1 presents data as of the AAER issuance date, which is typically well after the fraud occurred. We observe a similar pattern (untabulated) when we consider when the fraud actually occurred.

\section{- Insert Table 1 here -}

Consistent with these descriptive data, Cox and Thomas (2005) find that the SEC appears to be targeting much larger companies in the post-2002 period that it did from 1990-2002. They document that the average (median) market capitalization for SEC

\footnotetext{
${ }^{8}$ There is limited research on the role of SEC enforcement on improving accounting quality in companies. One notable exception is Kedia and Rajgopal (2011). They find that firms located closer to SEC offices and in areas with higher prior SEC enforcement activity are less likely to restate their financials. Moreover, the SEC is more likely to investigate firms located closer to its offices. However, Jennings, Kedia, and Rajgopal (2013) find that the deterrence effect of SEC enforcement actions is not reflected in improved earnings quality at peer firms as measured by abnormal accruals, earnings response coefficients or timely loss recognition.
} 
enforcement targets was 23 (13) times bigger post-2002. Dyck, Morse, and Zingales (2010) find that the SEC became more likely to be the first detector of corporate frauds after SOX, increasing its share of total fraud detection (relative to other actors) from 5\% to $10 \%$.

The pattern observed Table 1 and by Cox and Thomas (2005) could occur if the type of firms committing fraud has changed over time, with larger firms being prone to commit fraud now than before. Anginer et al. (2012) address this issue by examining firms that presented evidence of options backdating based on suspicious timing of option grants on dates where the stock price was at its lowest. Based on this sample of all potential backdating cases, they find that smaller firms were more likely to indulge in the practice than larger firms. However, they find that larger firms were more likely to be prosecuted by the SEC and DOJ. The effect of changing enforcement priorities on propensity to commit fraud in particular and on accounting quality in general is an open issue, and remains an unexplored potential consequence of (and/or confound for) SOX. For example, Section 408 of SOX required the SEC to review periodic financial statements of companies at least once every three years, representing a major step up from then existing review practice. The resulting publicly available comment letters present a rich source of data on financial reporting issues and a potential area for research.

\subsection{Role of boards and audit committees}

Section 301 of SOX required that the audit committee be comprised exclusively of independent directors and charged the audit committee with direct responsibility for the appointment, compensation, and oversight of the auditor. There is a preponderance of 
evidence (from mainly association studies) that more independent audit committees demand better audit quality and are associated with better financial reporting quality (e.g., Klein 2002; Abbott, Parker, Peters 2004). The previously discussed evidence on improvement in accounting quality post-SOX is consistent with improved monitoring by audit committees, though direct evidence of SOX mandates on audit committee independence contributing to this effect is lacking.

Section 407 of SOX required firms to comply with the requirement to have at least one audit committee financial expert, or explain why they did not, leading to the question of the role financial experts play in improving financial reporting. Defond, Hann, and Hu (2005) examine 3-day market reaction around director appointments to the board pre-SOX (1993-2002) and find a positive reaction to appointment announcement for accounting financial experts but no reaction to non-accounting financial experts or non-financial directors, suggesting that the market places a positive value on accounting experts. They document a positive reaction even if the board had a prior financial expert. The paper finds weak evidence that the market responds to expectations of better monitoring than the signal of quality when an expert joins the board. Accounting experts on the audit committee, in particular, improve accounting quality. Dhaliwal et al. (2010) find that audit committee accounting expertise is positively associated with accruals quality for audit committee accounting experts with lower tenure and fewer other directorships. Several papers use board changes prompted by changes in stock exchange listing requirements to examine the impact of board characteristics on a variety of firm outcomes. While interesting, we do not discuss these papers as they do not directly relate to the effect of SOX itself, which changed the requirements only for audit committees. 


\subsection{Effect of SOX on governance and transparency generally}

Hochberg et al. (2009) use an innovative approach to study wealth effects by examining stock market reaction for firms that lobby for or against the provisions of SOX. Greater returns to firms that lobby against strict implementation of SOX suggest SOX had a positive impact on corporate transparency and governance. Further they find that firms with corporate insiders that oppose strict SOX related rules are larger, are more profitable, have lower future growth opportunities, and retain more cash, all characteristics of free cash flow or agency problems. These firms experience higher cumulative abnormal returns during the SOX passage period relative to peer firms that choose not to lobby. These cumulative returns do not reverse themselves following the passage of SOX.

\subsection{Auditor performance in the financial crisis}

A last set of studies bears on how well auditors performed in the financial crisis, as one measure of whether SOX accomplished the goal of improving accounting and auditing. By that measure, the results are mixed. On the one hand, within a short time of receiving clean audit reports (and section 404 control attestations) from their auditors, many financial institutions failed in contexts calling into question their prior accounting. As reviewed in Sikka (2009), Bear Stearns received a clean report from Deloitte on January 28, and failed on March 14; Thornburg received a clean report from KPMG on February 27, which was withdrawn on March 4 prior to Thornburg's failure; Northern Rock received a clean report on July 25, only to suffer a bank run on September 14; and US Bancorp received a clean report from E\&Y on February 20 before receiving \$6 billion in bail-out funds on November 14. As detailed by a bankruptcy court examiner 
(Valukas (2010)), E\&Y “were aware of but did not question Lehman's use and nondisclosure" of "window-dressing" repo transactions to "manage" its balance sheet around period ends, ${ }^{9}$ to make it appear that it was smaller and less leveraged than it was, leading the examiner to conclude there was "sufficient credible evidence to support a finding by a trier of fact” that E\&Y had failed to meet professional auditing standards. Consistent with these examples, Desai, Rajgopal, and Yu (2013) find large sample evidence that auditors showed no ability to assess bank risk and predict weaknesses in the lead up to the financial crisis in contrast to the ability of short sellers to do the same.

On the other hand, a few studies suggest that some of the goals of SOX improved financial institutions in the crisis. Yeh et al. (2011) find in a cross-country study that banks with fully independent audit committees prior to the crisis performed better, measured by total return to shareholders and return on equity during both 2007 and 2008 . Jin et al. (2011) found that among small and mid-sized US banks, those with auditors that specialized in banking in 2006 were less likely to fail in the crisis (i.e., 2007 to 2009). Doogar, Rowe, and Sivadasan (2013) show that audit firms increased fees charged to their banking clients to reflect the changing risk profile of their loan portfolios and securitization risk over the time period from 2005 to 2007, suggesting that audit firms recognized client risk and priced their services accordingly. The authors attribute the failure by audit firms to provide advance warning of client failure to limitations in the auditor's report and the scope of the auditors disclosure requirements rather than to a failure of assess client risk. Together, the evidence suggests that better auditing and more

\footnotetext{
${ }^{9}$ On bank holding company window-dressing in the crisis generally, see Owens and Wu (2012).
} 
independent auditors did help alleviate the worst effects of the crisis, even if SOX, PCAOB and audit firms performed well below the ideal.

\section{$9 \quad$ A research agenda: SOX and beyond}

Drawing on the prior sections, we develop a research agenda that better grapples with difficulties of measuring the full set of costs and benefits caused by and not merely correlated with new financial regulations, such as SOX. To accomplish this general goal, multiple new research tasks must be engaged, including better estimates of fraud, new models and data on the externalities of fraud, new and better instruments for estimating causal effects of anti-fraud regulation, and better models and data on the chilling effects that financial regulation may have on legitimate activity. Each task will be difficult, and each will likely require a separate stream of research - both theoretical and empirical before any plausible aggregate estimate of the benefits of any major piece of financial regulation can be developed. While these tasks are being undertaken, regulation will continue to be produced, modified, and criticized by political actors, and we conclude with speculative suggestions on how policymakers might improve on financial regulation from a cost-benefit perspective without waiting on a fully realized research agenda.

\subsection{Estimating the incidence of fraud and its direct costs}

The first task is to develop better methods of simply measuring the incidence of fraud and its costs. This task is a necessary prerequisite before we can even roughly estimate the effect of regulation aimed at reducing fraud. Many papers link fraud to equity compensation for executives (e.g., Burns and Kedia (2006) and Johnson, Ryan and Tian (2009)) and non-independent or inexpert corporate boards (e.g., Agrawal and Chadha (2005)). Khanna et al. (2013) link fraud to CEO connectedness to other same- 
firm executives and directors. Dyck, Morse, and Zingales (2010) find that multiple monitoring agents play a role in detecting major corporate frauds, including auditors, analysts, and the SEC, but also newspapers, employees, and non-financial regulators. Other papers examine whether general measures of investor mood or beliefs are related to the overall incidence of fraud. ${ }^{10}$ For the most part, however, these studies only attempt to establish that relationships between incentives, monitoring agents or investor beliefs exist, and do not convincingly identify causality or present evidence of how strong these relationships are, or what the overall incidence of corporate fraud is.

One difficulty confronting such studies is that in observational or quasiexperiments set in the real world, the difficulty is that all concerned have incentives to hide fraud. ${ }^{11}$ Fraud is already subject to criminal and multiple civil penalties if discovered, so fraudsters have strong incentives to hide their activities. As with crime generally, regulators and enforcement officials, too, have at least some incentives to suggest that the incidence of undiscovered fraud is lower than it may actually be, since a large stock of undiscovered fraud might be used to attack their efficacy. Victims have incentives both to over-report fraud (in the wake of poor investment decisions, for example), but also to under-report it (because there are social and psychological costs to acknowledging that one has been duped). Lev (2003), who reviews large sample studies

\footnotetext{
${ }^{10}$ For example, Hertzberg (2005) and Povel, Singh, and Winton (2007) develop theories about whether and how the incidence of fraud should relate to investor optimism about business conditions. Hertzberg posits a positive relationship; Povel et al. argue instead for an inverted $U$ shaped relationship, peaking when investors believe conditions are good, but not extremely good. Wang, Winton and Yu (2010) apply the Wang empirical 2010 model to a sample of IPOs to test which of these theories better fits the data, and find that the latter does.

${ }^{11}$ In controlled experiments, by contrast, researchers can know with much greater certainty the actual incidence of fraud and the effects of different "regulatory" treatments (see, e.g., Guttentag et al. (2009), who study the effect of disclosure on fraud incidence in such an experiment). But the ability to generalize beyond such experimental research settings is unclear at best.
} 
of discontinuities in the distribution of public company earnings, deviations from expected accruals and patterns of earnings around suspicious circumstances, and concludes "this evidence suggests that the frequency of manipulations [of reported earnings] is substantially higher than the 100-150 litigated or SEC-enforced cases per year.” As analyzed by Feinstein (1990), partial observability presents challenges to empirical modeling.

Wang (2010, 2013) and Li (2013) use empirical models of both fraud incidence and detection that allows better inferences about the correlates of fraud (including both detected and undetected fraud) to be drawn from detected frauds. ${ }^{12}$ Each exploits the partial overlap in indicators of both fraud incidence and fraud detection, using different econometric models. ${ }^{13}$

Building on Wang's work, Dyck, Morse and Zingales (2013) exploit the failure of Arthur Andersen, which forced companies to change auditors, and on the assumption that new auditors would "clean house” and reveal fraud that might otherwise have been unrevealed. They estimate that the probability of a public company engaging in fraud in any given year is $15 \%$ - which would suggest a current stock of several hundred fraudulent public companies. (They validate this measure with a survey of fraud observed by business school students at former employers.) Dyck et al. 2013 estimate the

\footnotetext{
${ }^{12}$ While the fraud prediction and detection models in these papers allow better assessment of fraud, concerns still remain about the exogeneity of the instruments used to model underlying fraud as distinct from detected fraud.

${ }^{13}$ Wang finds $\boldsymbol{R} \& \boldsymbol{D}$ (but not capex), abnormally low accounting or stock returns, and high stock turnover make fraud more likely, while fraud is less likely if a firm faces more analyst coverage; fraud detection, by contrast, is increased by M\&A and analyst coverage, but decreased by R\&D expenditures. Li finds that fraud incidence is increasing in executive pay performance sensitivity and decreasing in institutional ownership, while fraud detection is increasing in qualified audit opinions and the SEC's inflationadjusted budget per public company.
} 
average corporate fraud generates losses of between $22 \%$ and $40 \%$ of enterprise value (equity plus long-term debt) at a fraudulent firm. In combination, these two estimates $(0.15 \times 0.22=0.03)$ estimate an aggregate lower bound on the cost to investors in fraudulent firms of roughly $3 \%$ of enterprise value. Applied to the market capitalization of all US public companies, this implies a total as-yet-unrevealed direct cost to investors of over $\$ 500$ billion. A reduction by just $1 \%$ in this incidence of fraud would generate $\$ 5$ billion of direct benefits to current investors - before accounting for the indirect costs of fraud (discussed below).

Zakolyukina (2013) estimates undetected intentional earnings manipulation from a sample of 1,500 firms in the post-SOX period. She finds that the probability of detection is only $9 \%$, and generates a loss of $11 \%$ to the firm's CEO wealth if detected. The inference she draws is that $66 \%$ of her sample have rational incentives to manipulate earnings, and that the value-weighted bias in stock prices across the sample firms is $16 \%$ - in line with the Dyck et al. estimate of the direct investor losses caused by fraud. Finally, Karpoff, Lee, and Martin (2008a) provide estimates of the costs borne by firms that engage in fraud, and their managers. Firms that misrepresented in the pre-SOX period and were subject to SEC AAERs incur penalties of \$24 million per firm, but lose 7.5 times more (on a present value basis) in the form of lower sales and higher contracting and financing costs. For each dollar a firm inflated its market value, it lost $\$ 4.08$ once the misconduct is revealed $-\$ 0.36$ due to SEC penalties and $\$ 3.83$ to reputation. Survey evidence in Dichev, Graham, Harvey and Rajgopal (2013) suggests that around 20 percent of firms exploit GAAP to misrepresent reported performance in financial statements. 
These studies, while helpful in at least bounding the incidence of certain types of fraud, are limited in various ways, and include different factors. Future research could aim at more comprehensive measures of fraud, to include not only auditor-discoverable fraud (studied in Dyck et al.) and earnings manipulation (studied in Lev 2003 and Zakolyukina 2013), but also frauds that fall outside the scope of audits, such as insider trading, self-dealing (as at Enron), fraud-based compensation (as at Tyco), frauds involving third parties (as at Worldcom) or technically GAAP-compliant but deceptive accounting choices (as arguably was true at Lehman). As an example, Anginer et al. (2012) identify suspicious options backdating activity by identifying likely opportunistic option grants that are made at unusually favorable exercise prices. This allows them to identify a sample - an upper bound - of all possible backdating cases from where they identify firms that were prosecuted by the SEC. At a minimum, we suggest a better comprehensive data collection effort by all enforcement officials, across all relevant regulatory agencies (SEC, CFTC, CFPB, FTC, Fed, OCC, FDIC, DOJ, FINRA, PCAOB, state agencies and AGs), to identify aggregate trends in the incidence of fraud. A companion effort might be for the same agencies to create a single point-of-entry webbased system for whistle-blowers, victims, and others to report suspicious or potentially fraudulent activity, which could provide directional if noisy data on as-yet unproven fraud.

\subsection{Modeling and measuring the externalities of fraud}

If more work needs to be done on models of fraud incidence, the equally important task of estimating the costs of fraud remains farther behind. Few researchers have systematically attempted to study and measure the social costs of financial frauds. 
Without such estimates, an assessment of a regulation that reduces fraud would remain qualitative. Research particularly needs to be conducted on the extent to which fraud results not only in direct monetary net losses to the parties involved (the focus of Dyck et al. 2013, discussed above), but in both psychological costs and externalities. ${ }^{14}$ Psychological effects (e.g., fear, distrust, and stress) can result in tangible consequences, including drug addiction, job loss, reduced income, health effects, and even suicide. In the context of securities fraud, Freshman (2012) finds elevated levels of post-traumatic stress disorder and related behavioral effects among Madoff victims. On the externalities of fraud, Lev (2003)'s sketch is a useful starting point for the following categories: ${ }^{15}$

(a) Fraud increases the cost of capital for all firms, due to reduced quality of financial information and heightened expected fraud-related losses and reduced confidence in public securities markets and in markets more generally. ${ }^{16}$

\footnotetext{
${ }^{14}$ Fraud is criminalized in part for these reasons - direct remediable civil damages are not thought to be large enough to provide sufficient incentive for private actors to enforce optimally. Shavell 1986. But criminal sanctions are reserved for a small subset of frauds - those in which clear evidence is available ex post for frauds caused by individuals with specific intent, and the nature of fraud is such that such evidence is often unavailable. section 24 of the Securities Act of 1933 imposes criminal liability for "willful" violations; see also section 32(a) of the Securities Exchange Act of 1934 (same).

${ }^{15}$ Anderson (1999) presents a similar list of indirect effects of crime generally. He estimates the indirect costs - what he categorizes as "crime-induced production," opportunity costs, and risks to life and health are roughly double the value of victim-to-criminal property transfers, and when he counts the costs incurred by criminals, the total costs of crime is more than double the value of those transfers (Table 7). In other words, the external effects of crime generally greatly exceed their direct effects. See also Velikonja (2013).

${ }^{16}$ Jain, Kim and Rezaee (2008) show that market liquidity deteriorated following Enron and related scandals, and improved after SOX's adoption, and Gianetta and Wang (2013) show that revelation of corporate frauds in a state caused equity holdings of households in that state to fall, increasing the cost of capital for nonfraudulent firms. For a more general study of the effect of trust on finance, see Guiso et al. 2007; see also Bonaccorsi di Patti 2009 (crime, including fraud, increases borrowing costs and increases capital constraints).
} 
(b) Fraud wastes investment caused by misallocation of resources caused by fraudulent signals of the value of firms or whole industries, as in the telecom and internet bubbles. ${ }^{17} 18$

(c) Fraud destroys value through the (costly) acquisition by fraudulent companies of other companies, followed by mismanagement or outright theft and bankruptcy, causing further transaction costs of reorganizing still-viable companies once the fraud is uncovered. ${ }^{19}$

(d) Fraud induces increased bonding, monitoring and precautionary costs by investors to avoid fraud, such as for audit firms, independent directors, appraisers, analysts, regulatory and enforcement agencies, and prisons. ${ }^{20}$

(e) Fraud imposes costs imposed on third parties that are dependent on the victims of the initial fraud (e.g., family, business partners, creditors and communities). ${ }^{21}$

\footnotetext{
${ }^{17}$ For a review of studies showing that corporate finance decisions driven by capital market prices, including prices that deviate from fundamental values (i.e., mispricing), see Baker 2009; see also Baker, Stine and Wurgler 2003 (modeling and presenting evidence that bubbles affect corporate investment).

${ }^{18}$ Kedia and Phillippon (2009) model investment decisions of firms during periods of fraud and find empirical support for their prediction that fraud and earnings management distort hiring and investment decisions of firms leading to over-investment and excessive hiring during periods of suspicious accounting. This leads to misallocation of resources in the economy.

${ }^{19}$ For a model of merger and acquisition activity driven by mispricing, see Shleifer and Vishny 2003; for estimates of the costs of bankruptcy, see, e.g., Bris, Welch and Zhu 2006 (estimating range from 2 to 20\% of firm assets resulting from formal bankruptcy).

${ }^{20}$ As noted above, audit fees were rising prior to SOX, due to market-driven demand for increased scrutiny of financial statements following the scandals that led to SOX. See Asthana, Balsam, and Kim 2009. Likewise, separate from SOX, the NYSE and the Nasdaq adopted tighter corporate governance requirements in response to Enron et al., which tightened the criteria for and likely increased the costs of recruiting independent directors.

${ }^{21}$ For studies showing spillover effects of restatements, see Gleason, Jenkins and Johnson (2008) (spillovers on same-industry companies); Durnev and Mangen 2009 (same); Files and Gurun 2011 (spillovers on competitors, customers or suppliers of the restating firm). Karpoff, Lee and Martin (2008b) find that of 2,206 individuals identified as responsible for a set of 788 SEC and DOJ enforcement actions for financial misrepresentations, 93\% lost their jobs, most suffered significant financial losses, and $28 \%$ faced criminal charges and penalties, including prison sentences averaging 4.3 years. Their results imply
} 
For example, consider the likely size of such costs flowing from the Madoff scandal, which imposed significant direct losses on over 15,000 individual investors, each of whom presumably had an average of two dependents or heirs, and many of whom were co-investors and borrowers with yet others, or makers of charitable donations to non-profits. ${ }^{22}$ To date, the liquidation of the Madoff entities has generated over $\$ 700$ million in expenses - all a pure loss to investors, over and above the amounts stolen by Madoff himself. ${ }^{23}$ As a broader example, consider how fraudulent home loans (whether due to borrower fraud, lender fraud, or both) had ripple effects in the last financial bubble, partly generated through leverage and intermediation, so the one fraudulent loan would affect not only the immediate parties to the loan but also securitization lenders, sponsors and other related parties; collateralized debt obligation investors, sponsors and related parties; structured investment vehicle (SIV) investors, sponsors and related parties; investors in the banks that sponsored the SIVs; borrower-customers of those banks, whose capital constraints and heightened risk-aversion following the crisis caused a withdrawal or increase in the cost of credit; employees and customers of businesses that failed as a result of the capital constraints generated by the banks' losses; family members of those employees, and so on.

How do we translate these anecdotal examples into a more general method for estimating not just the losses to fraud victims, but the more general knock-on effects of

\footnotetext{
that the 788 frauds generated led to 2,656 prison-years, roughly totaling $\$ 79$ million for prison costs alone, based on BJS (2008) data on average prison costs.

${ }^{22}$ See Picard 2013 at Exhibit A, page 5. For charities harmed by the Madoff scandal, see Weiss and Birkner 2008.

${ }^{23}$ See Picard 2013 at Exhibit A, page 2.
} 
fraud on society as a whole? In the context of SOX specifically, Graham, Litan and Sukhtankar (2002) is an isolated effort to estimate fraud's social costs from stock market price changes arguably induced by fraud. They relate large-scale instances of fraud revelation (as in the period leading up to SOX) and the direct costs they impose on investors on the fraudulent companies to models of the role of the stock market in the macro-economy. The authors draw on the discussion of "shocks" to the equity premium in the broader analysis in Reifschneider, Tetlow and Williams (1999) of the "US/Fed model” used by the Treasury Department and the Federal Reserve to model the US economy for purposes of setting monetary policy. In another attempt to assess externalities from fraud, Gianetti and Wang (2013) use brokerage data of a sample of retail investors across the US and show that upon the revelation of fraud in a company in a particular state, all households in the state, not just the ones owning stocks of fraud firms, reduce their equity holdings. Households also decrease their ownership in all firms, not just the ones where fraud is revealed. Firms headquartered in the same state as a firm involved in fraud experience a decline in the number of shareholders, especially retail ones. Relatedly, same state firms also experience an increase in cost of capital and lower valuations.

Graham et al. first develop a rough range of estimates of the direct costs to investors of the pre-SOX scandals, ranging from $\$ 10$ to $\$ 23$ billion, based on assuming that between 25\% and 100\% of the market decline from March 2002 to July 2002 was caused by those scandals. They then combine these estimates with the US/Fed model's prediction that investment would fall $0.8 \%$ per year in response to a $20 \%$ decline in stock market wealth, to estimate the first-year impacts of the scandals on the economy as a 
whole, producing social estimates of the costs of the scandal ranging from $\$ 19$ billion to \$57 billion. Graham et al.'s estimates would understate actual costs if the impact on US GDP lasted for more than one year.

For similar models of the social costs of financial crises, such as the recent one, see Haldane (2010) (estimating that the recent crisis caused losses of between 90\% and 350\% of world GDP); De-Ramon, et al. (2012) (estimating the recent crisis caused losses of between $18 \%$ and $48 \%$ of UK GDP); and Posner and Weyl (2013) (estimating the losses at between $1 \%$ and $20 \%$ of US GDP). As can be seen from the range of estimates from these studies, the models remain highly sensitive to assumptions, and produce highly varying results. Even if one thinks that "ordinary" corporate fraud produces less dramatic effects on the financial system as a whole than was the case in the recent crisis, considerably more work remains to be done to be able to estimate the social costs of financial fraud in this way.

Finally, research on corporate fraud could learn from research on crime generally, which uses several families of methods (see Ludwig 2010 and Donohue 2009 for overviews): (1) "hedonic" models in which changes or variation in market prices affected by crime to infer social costs (e.g., Thaler 1978, Hoehn Berg and Blomquist 1987, Viscusi 2000); (2) the use of surveys of willingness-to-pay by potential victims for a reduction in the odds of crime (e.g., Cohen et al. 2004; Nagin et al. 2006); (3) estimating each of the direct and indirect effects separately and aggregating them (e.g., Anderson 1999); and (4) relating responses to surveys of crime victims to respondent wealth or income and inferring a "shadow price" for the effects of crime (e.g., 
Moore and Shepherd 2006). ${ }^{24}$ Each method has limitations and weaknesses, and is probably best used in combination to produce cost ranges, as in Donohue 2009.

\subsection{Estimating causal effects of financial regulation}

With a better framework for estimating the incidence and costs of fraud in hand, researchers could then better estimate the benefits of specific legal or regulatory changes, such as reflected in SOX. To date, however, most studies of SOX (as reflected in our discussion above), have not used research designs well adapted for this purpose, and instead use simple before-and-after comparisons that fail to control for contemporaneous changes in the objects of study. Studying such changes is much harder than rocket science, which after all models relatively simple inert objects moving through space, and not large groups of independent agents interacting in a complex regulatory and market environment. Given the complexity of the task and the inevitably low power of such studies, we continue to need to find better quasi-experimental designs to better control adequately for omitted variables and identify causal effects.

Better are difference-in-difference designs, such as those used by Kamar et al. 2009 (studying going private), Johnson and Madura 2009 (studying going public); Piotorski and Srinivasan 2008 (studying foreign listings); Kang et al. 2010 and Bargeron, Lehn and Zutter 2010 (studying investment decisions). Even those studies can also be misleading if factors affect events in the nominal control sample in a similar fashion as in

\footnotetext{
${ }^{24}$ An open conceptual issue is whether to count the utility of a criminal in estimating social welfare effects of crime. Assume, for example, a fraudster obtains $\$ 1$ from a victim and spends it on food. Is the direct social loss $\$ 0$ or $\$ 1$ ? If the criminal's utility is ignored and the fraud has no effect besides the transfer of $\$ 1$, the social loss is $\$ 1$. If the criminal's utility is counted equally with the victim's, and neither attaches unusual utility to the $\$ 1$, the social loss is $\$ 0$. As outlined above, such fraud generates other losses, such as precautionary expenditures and externalities, but the question of how to count gains or benefits to fraudsters remains disputed. Compare Cook (1983) (criminals' utility should count) with Cohen (2005) and Ludwig (2006) (it should not count). Anderson (1999)'s data suggests the difference is significant.
} 
the nominally "treated" sample, as seems to be true for the investment decision studies. Better still are discontinuity designs, used by Iliev 2010 (studying changes in audit costs and accounting quality); Albuquerque and Zhu (2013) (studying investment decisions), but the findings of such studies may not generalize beyond the immediate discontinuity in question. Perhaps best of all are time-series designs studying multiple events, such as used by Leuz et al. 2008 (several events in the phase-in and extended exemptions for small firms from compliance with section 404) and Arping and Sautner 2013 (staged phase-in for foreign firms cross-listed in the US to comply with section 404). But it is rare to find multiple, objective and independent events in legal or accounting rulesystems with related implications.

\subsection{Modeling and measuring chilling effects of financial regulation}

Just as better causal designs are needed to study the effects of regulatory changes, so too are better designs for studying their costs. This is true even of direct costs, given the incentives of affected companies to exaggerate those costs in public comments, and the fact that most regulatory burdens will have a fixed, up-front component and a smaller ongoing cost, and can be reduced over time as compliance technologies improve. But the need is even greater with respect to indirect costs such as changes in risk-taking and investment, which can plausibly dwarf the direct costs in magnitude. SOX, for example, is said to have caused changes in the risk of personal liability facing managers and directors and in the risk of reputational harms and opportunity costs created by litigation. If true, difficult-to-explain and legitimate business risks may be foregone, firms may decline to go public or otherwise avoid the burdens of the law, with resulting social costs. These costs are likely to affect more firms, including firms not yet created, than the out- 
of-pocket costs of compliance at the time a law is initially adopted. Better specification and measurement of indirect costs, and better causal designs to estimate their magnitudes, will reduce the uncertainty associated with the net effects of any given regulatory change.

\subsection{Regulatory Experiments}

The difficulty in assessing causal effects of regulation arises from our inability to conduct a randomized trial. As discussed earlier, the staggered implementation for companies of different sizes and size cut-off for Section 404 applicability have provided the best experimental settings for causal analysis of costs and benefits of SOX. Prior experience suggests a few useful approaches to improve our ability to assess costs and benefits with some degree of causal inference. The SEC in implementing Regulation SHO (regulation of short selling effective January 2005) adopted a randomized testing approach in allowing a temporary suspension of some short-sale restrictions (price tests) for a set of roughly one thousand US stocks - the "Pilot" stocks were randomly selected to be every third from the Russell 3000 index ranked by trading volume. Diether, Lee and Werner (2009) use this randomization to assess the effectiveness of price tests and find that the rules introduce distortions in order flow thus affecting market quality. Similar randomization in implementation of important rules for large enough samples can allow for causal inferences.

A second approach is to allow voluntary opt-in or opt-out of regulations. While the voluntary nature of the opting decision introduces endogeneity concerns, this method allows for less costly trials since companies that find regulations costly are more likely to opt out. For example, Szewczyk and Tsetsekos (1992) examine Pennsylvania Senate Bill 1310 that introduced sweeping anti-takeover protection but allowed companies the option 
to reject or retain provisions of state level anti-takeover provisions. They find an abnormal stock return of about negative 9 percent from introduction to enactment of the bill and a positive abnormal two-day return of 0.65 percent for firms that rejected all provisions of the bill. Manzi (2012) discusses several experiments in Welfare Reform in the US where individual states were allowed to opt out of federal regulations in return for data collection on several outcomes, which eventually led to scientific evidence on the efficacy of the programs.

\subsection{What to do in the meantime?}

Here we return to the fact that many costs (direct costs) are easier to observe and quantify (even if such estimate are likely to be overstated), while other costs (opportunity, risk-taking) are hard to observe and quantify, and the benefits being hardest to estimate of all. This raises a methodological challenge for policy-makers: if they are truly neutral on the net costs/benefits coming to the analysis, they have to implicitly weight the results of quantitative assessments differently, given the difference in ease of quantifying costs / benefits.

One way to address this imbalance might be to develop a “multiplier” for fraud’s costs, and for the benefits of reducing fraud through any given regulatory change. This multiplier would be similar to the multiplier used to estimate the effects of government spending on economic growth - with all of the controversy that the analogy suggests, whatever the result of the debate over the size of the multiplier, it would be better than either accepting zero as the implicit number for difficult-to-quantify benefits of anti-fraud regulation within a cost-benefit framework, or to decline to pursue quantification 
altogether, relying solely on faulty and politically influenced regulatory judgments of elected lawmakers and appointed regulatory officials.

Alternatively, policy-makers can put together and refine but rely on admittedly crude assumptions such as those used by Dyck et al. 2013 and Graham et al. 2002, discussed above. Such methods will create ballpark estimates of the benefits of tightened financial regulations, which can then be used to compare to equally crude estimate of such regulations' costs. Even crude efforts at quantification of the full range of regulatory costs and benefits will at least focus public and policy debate on common questions. Without it, result is likely to be continued polarization over financial regulations' effects, and continued vacillation between excessively tight and excessively permissive laws.

\section{Conclusion}

Coming in the aftermath of several large-scale frauds in the early 2000s, SOX sought to empower regulators, auditors, and corporate boards to improve governance and reduce fraud. With the passage now of over ten years, there is substantial research on the consequences of the Act. We assess the impact of SOX using findings from scholarly research to help researchers understand the strengths and limitations of current research in informing about significant regulatory interventions as well as to inform regulators and policy makers on the design of future regulations or changes to current ones.

We find that despite its controversial nature, the Act has survived almost intact since its enactment. The PCAOB has become an important part of the regulatory landscape having survived a high profile lawsuit that challenged its constitutionality. Our 
survey suggests that some of the early concerns about SOX were likely overblown. There is scant evidence of "federalization" of corporate law. Significant modifications to the implementation of SOX's core provision relating to internal controls - section 404, have made it less costly to implement and hence more acceptable.

Several studies that have estimated the direct costs of SOX (especially section 404) implementation and find that these costs fall disproportionately on smaller firms. Modification to section 404 and subsequently the JOBS Act were aimed at lowering the cost imposed on smaller firms. In terms of indirect costs, we conclude that the evidence of costs is not clear cut. While several smaller firms left the public equity market and smaller foreign firms shunned the US as a listing venue, these firms fit the profile of firms more susceptible to fraud (and also reflect reversal from a higher propensity in the mid-1990s for smaller firms to access public equity markets). Hence, the social welfare implication of implicitly deterring these smaller firms from public markets is unclear. A more serious concern is the documented decline in investments to capital ratio in the US post-SOX, with implications for innovation and risk taking in the US economy. However, research also documents that the trend towards lower investments started prior to SOX and the post-SOX trend is merely a continuation of a prior pattern. We conclude that while there is some evidence on indirect costs, research presently has not produced robust evidence on the cause or the magnitude of the effect.

Research has documented benefits in financial reporting quality after SOX. While there is a significant time period effect, there is less evidence on the causality. The staggered implementation of SOX 404 allowed researchers to produce some causal evidence that section 404 implementation has produced financial reporting benefits. 
There is also significant evidence that internal control weakness reports produced as a result of section 404 are valuation relevant for investors and prompt companies to make managerial and governance improvements. Overall, there appears to have been an improvement in financial reporting quality after SOX, some of which can be attributed to section 404.

We conjecture that the policy opposition to SOX is driven to a large extent by the observable direct costs. Estimating the benefits and indirect costs are difficult tasks, made even harder by the difficulty of drawing causal inferences about the Act's effects. Further, without a better handle on the externalities created by frauds, it is hard to assess costs and benefits of regulation designed to combat fraud. We make several suggestions in the short and long term that researchers and policy makers can adopt. The first task is to estimate the extent of the incidence of fraud (not just fraud that is detected) and then to model and measure the externalities caused by fraud. The next task would be to estimating the causal effects of regulation aimed at combating fraud. And the third task is to model and measure the negative effects of regulation. Together these tasks are challenging but critical to ensure policy making is well informed by research. 


\section{References}

Abbott, L.J., Parker, S., Peters, G.F., 2004. Audit committee characteristics and restatements. Auditing: A Journal of Practice and Theory 23(1), 69-87.

Agrawal, A., and S. Chadha, 2005. Corporate governance and accounting scandals, Journal of Law and Economics, Vol. 48, pp. 371-406.

Akhigbe, Aigbe, and Anna Martin. 2006. Valuation Impact of Sarbanes-Oxley: Evidence from Disclosure and Governance within the Financial Services Industry," Journal of Banking and Finance, Vol. 30, 989-1006.

Albuquerque, A. M. and Zhu, J. L., 2013. Has Section 404 of the Sarbanes-Oxley Act Discouraged Corporate Risk-Taking? New Evidence from a Natural Experiment. Working paper Available at SSRN: http://ssrn.com/abstract=1997228.

Alexander, C. R. and S.W. Bauguess, G. Bernile, Y. A. Lee., and J. Marietta-Westberg. 2013. Economic Effects of SOX Section 404 Compliance: A Corporate Insider Perspective Journal of Accounting \& Economics, Forthcoming

Altamuro, J. L., Beatty, A. L. 2010. How Does Internal Control Regulation Affect Financial Reporting?. Journal of Accounting and Economics, Vol. 49, Issue 1-2, 5874.

Anderson, D., 1999. The aggregate burden of crime, Journal of Law and Economics, Vol. 42, No. 2, pp. 611-42 (Oct. 1999).

Anginer, Deniz., Narayanan. M.P., Cindy Schipani, and Nejat Seyhun. 2012. "Should size matter when regulating firms? implications from backdating of executive options,” N.Y.U. Journal of Legislation \& Public Policy 15, 1-44, 2012.

Arping, S. and Sautner, Z. 2013. Did SOX section 404 make firms less opaque? Evidence from cross-listed firms. Contemporary Accounting Research, 30: 1133-1165

Ashbaugh, H., R. LaFond, and B. W. Mayhew. 2003. Do Nonaudit Services Compromise Auditor Independence? Further Evidence. The Accounting Review 78 (3):611-639.

Ashbaugh-Skaife, H., Collins, D.W., Kinney, W.R., Lafond, R., 2008. The effect of SOX internal control deficiencies and their remediation on accrual quality. The Accounting Review 83, 217-250.

Ashbaugh-Skaife, H.D., W. Collins, W.R. Kinney and R. LaFond. 2009. The effect of SOX internal control deficiencies on firm risk and cost of equity. Journal of Accounting Research 47 (1): 1-43. 
Asthana, S., S. Balsam, and S. Kim., 2009. "The Effect of Enron, Andersen, and Sarbanes-Oxley on the Market for Audit Services," Accounting Research Journal Vol. 22, No. 1.

Baker, M, 2009. Capital Market-Driven Corporate Finance, Annual Review of Financial Economics 1, no. 1 (December 2009): 181-205.

Baker, M., J. Stein and J. Wurgler, 2003. When does the market matter? Stock prices and the investment of equity-dependent firms. Quarterly Journal of Economics, pp. 9691005.

Bargeron, L., K. Lehn, and C. Zutter, 2010, “Sarbanes-Oxley and corporate risk-taking,” Journal of Accounting and Economics 49, 34-52.

Bartlett, R., 2006, Going private but staying public: reexamining the effect of SarbanesOxley on firms’ going private decisions, Chicago Law Review, Vol. 76, pp. 7-43.

Bartov. E., and Cohen, D. 2009. The 'Numbers Game' in the Pre- and Post-Sarbanes Oxley Eras. Journal of Accounting, Auditing, and Finance 24(4), Fall: 505-534.

Bates, Thomas, Kathleen Kahle, and René Stulz, 2009, Why do US firms hold so much more cash than they used to? Journal of Finance 64, 1985-2022.

Bazerman, M. H., and D. A. Moore. 2011. "Is It Time for Auditor Independence Yet?" Accounting, Organizations and Society (December 2011).

Bebchuk, L. A., Bachelder, J., Campos, R. C., Georgiou, B. S., Hevesi, A. G., Lerach, W., Mendelsohn, R., Monks, R., Myerson, T., Olson, J. F., Strine, L., Wilcox, J. C. 2006. “Director Liability.” Delaware Journal of Corporate Law, Vol. 31, No. 3, pp. 1011-1045, 2006

Bhattacharya, Utpal., P. Groznik, and B. Haslem. 2007. Is CEO Certification of Earnings Numbers Value-Relevant?. Journal of Empirical Finance, 2007, vol 14, 611-635

Black, B., Cheffins, B., Klausner, M., 2006a. Outside director liability. Stanford Law Review 58, 1055-1160.

Bonaccorsi di Patti, E., 2009, Weak institutions and credit availability: the impact of crime on bank loans, Working Paper (July 2009), available at http://ssrn.com/abstract=1606242.

Bova, F., M. Minutti, G. Richardson, and D. Vyas. "The Impact of SOX on the Exit Strategies of Private Firms.” 2013, Contemporary Accounting Research, forthcoming 
Brau, J. C. and Fawcett, S. E. (2006), Initial Public Offerings: An Analysis of Theory and Practice. The Journal of Finance, 61: 399-436

Bris, A., I. Welch and N. Zhu, 2006, The costs of bankruptcy: Chapter 7 liquidation versus Chapter 11 reorganization, Journal of Finance, vol. 61, pp. 1253-1303 (June 2006).

Brochet, F., 2010. Information content of insider trades before and after the SarbanesOxley Act. The Accounting Review 85(2), 419-446.

Brochet, F., and S. Srinivasan. 2013. "Accountability of Independent DirectorsEvidence from Firms Subject to Securities Litigation." Journal of Financial Economics (forthcoming).

Burch., R. F., 2006. Director Oversight and Monitoring: The Standard of Care and the Standard of Liability Post-Enron, 6 Wyo. L. Rev. 482 (2006).

Burks, J. J. 2010. Disciplinary Measures in Response to Restatements After SarbanesOxley. Journal of Accounting and Public Policy 29(3): 195-225.

Burks, J.J., 2011. Are investors confused by restatements after Sarbanes-Oxley? The Accounting Review 86(2), 507-539

Burns, N. and S. Kedia, 2006, The impact of performance-based compensation on misreporting, Journal of Financial Economics, vol. 79, pp. 35-67 (2006).

Butler, H. N., and L. E. Ribstein. 2006. The Sarbanes-Oxley Debacle: How to Fix It and What We've Learned. Washington, DC: American Enterprise Institute Press

CAQ 2010, Center for Audit Quality, The CAQ’s Fourth Annual Individual Investor Survey (September 2010).

Carter, M.E., L.J. Lynch, and S.C. Zechman, 2009, Changes in bonus contracts in the post-Sarbanes-Oxley era, Review of Accounting Studies 14(4).

Cheng, Mei., Dhaliwal, Dan S. and Zhang, Yuan, 2013. Does Investment Efficiency Improve after the Disclosure of Material Weaknesses in Internal Control over Financial Reporting? Journal of Accounting \& Economics, 56, 1-18.

Cheng, B., S. Srinivasan., and G. Yu. 2013. Securities Litigation Risk for Foreign Companies Listed in the US Available at SSRN: http://ssrn.com/abstract=2163864

Chhaochharia, V., and Y. Grinstein. 2007. Corporate governance and firm value: the impact of the 2002 governance rules. Journal of Finance 62 (2007): 1789-1825. 
Chung, H., and S. Kallapur. 2003. Client Importance, Nonaudit Services, and Abnormal Accruals. The Accounting Review 78 (4):931-955.

Coates, J. C. IV. 2007. “The Goals and Promise of the Sarbanes-Oxley Act.” Journal of Economic Perspectives 21 (2007): 91-116.

Coates, J. C. IV. 2014. Cost-Benefit Analysis of Financial Regulation: Case Studies and Implications, Working Paper (2014), available at http://ssrn.com/abstract=2375396.

Coffee, John C., Jr., 1999, The future as history: The prospects for global convergence in corporate governance and its implications, Northwestern University Law Review 93, 641-708.

Cohen, J. R. and C. Hayes, G. Krishnamoorthy, G. S. Monroe, and A. Wright., The Effectiveness of SOX Regulation: An Interview Study of Corporate Directors (February 26, 2013). Behavioral Research in Accounting, Vol. 25, No. 1, 2013.

Cohen, D., A. Dey, and T. Lys, 2008, "Real and accrual-based earnings management in the pre- and post-Sarbanes Oxley periods," The Accounting Review 83, 757-787.

Cohen M., R. Rust, S. Steen, S. Tidd, 2004, Willingness-to-pay for crime control programs. Criminology, vol. 42, pp. 86-106.

Cohen M., 2005, The costs of crime and justice. Routledge, New York, NY

Cook, Philip J. 1983. “Costs of Crime,” in Encyclopedia of Crime and Justice. Sanford H. Kadish, ed. New York: Free Press.

Costello, A. M. and Wittenberg-Moerman, R., 2011. The Impact of Financial Reporting Quality on Debt Contracting: Evidence from Internal Control Weakness Reports. Journal of Accounting Research, Vol. 49 No. 1.

Cox, James D. and Thomas, Randall S., 2005. Public and Private Enforcement of the Securities Laws: Have Things Changed Since Enron?. Notre Dame Law Review, Vol. 80.

Cox, James D., Strengthening Financial Reporting: An Essay On Expanding The Auditor's Opinion Letter, Geo. Wash. L. Rev., Vol. 81, pp. 1036-1061.

CRA 2005. Charles River Associates, Sarbanes-Oxley Section 404: Costs and Remediation of Deficiencies.

Daniel, N., Denis, D., and Naveen, L. 2008. "Do firms manage earnings to meet dividend thresholds?” Journal of Accounting and Economics 45. (Mar 2008):2-26 
Dechow, P. M., Ge, W., Larson, C. R. and Sloan, R. G. (2011), Predicting Material Accounting Misstatements. Contemporary Accounting Research, 28: 17-82.

Dee, C. C., A. Lulseged, and T. Zhang. 2011. Client stock market reaction to PCAOB sanctions against a Big 4 auditor. Contemporary Accounting Research 28 (1): 263291.

DeFond, M. L., K. Raghunandan, and K. R. Subramanyam. 2002. Do Non-Audit Service Fees Impair Auditor Independence? Evidence from Going Concern Audit Opinions. Journal of Accounting Research 40 (4):1247-1274.

DeFond, M. L., Hann, R. N. and Hu, X. (2005), Does the Market Value Financial Expertise on Audit Committees of Boards of Directors?. Journal of Accounting Research, 43: 153-193.

DeFond, Mark L. and Lennox, Clive S. 2011. The Effect of SOX on Small Auditor Exits and Audit Quality Journal of Accounting and Economics, Vol. 52, pp. 21-40.

DeFond, M. L. and Jeiying Zhang. 2013 “A review of archival auditing research”, forthcoming, Journal of Accounting and Economics

De-Ramon, S. et al., 2012, Measuring the impact of prudential policy on the macroeconomy: a practical application to Basel III and other responses to the financial crisis, FSA Occasional Paper Series 42 (May 2012)

Desai H., S. Rajgopal, and J. Yu. 2013. Did information intermediaries see the warning signals of the banking crisis from leading indicators in banks' financial statements? Forthcoming Contemporary Accounting Research.

Dhaliwal, D.S., Vic Naiker and Farshid Navissi. 2010. “The Association Between Accruals Quality and the Characteristics of Accounting Experts and Mix of Expertise on Audit Committees.” Contemporary Accounting Research. Fall 2010.

Dichev, I., J. Graham, C. Harvey, and S. Rajgopal. 2013. Earnings Quality: Evidence from the Field, Journal of Accounting and Economics, Volume 56, Issues 1-2, Supplement 1, December 2013, pages 1-33.

Diether, M., J. Lee, and J. Werner, 2009, It's SHO Time! Short-Sale Price Tests and Market Quality, The Journal of Finance 64, 37-73

Doogar, R., Sivadasan, P., Solomon, I., 2010. The regulation of public company auditing: Evidence from the transition to AS5. Journal of Accounting Research 48(4), 795-814 
Doogar, R., S. Rowe and P. M. Sivadasan, 2013, “Asleep at the Wheel (Again)?

Evidence from Bank Audits During the Financial Crisis.” Forthcoming, Contemporary Accounting Research.

Donohue, J. 2009. in Assessing the Relative Benefits of Incarceration: The Overall Change over the Previous Decades and the Benefits on the Margin, Do Prisons Make Us Safer? The Benefits and Costs of The Prison Boom (eds., S. Raphael and M. Stoll), New York: Russell Safe Foundation (2009).

Doyle, J., W. Ge, and S. McVay. 2007. Accruals quality and internal control over financial reporting. The Accounting Review 82 (5): 1141-1170.

Durnev A., and C. Mangen, Corporate investments: learning from restatements, $47 \mathrm{~J}$. Acct. Res. 679 (2009).

Dyck, A., Morse, A., Zingales, L., 2010. Who blows the whistle on corporate fraud? Journal of Finance 65, 2213-2253.

Dyck, A., Morse, A., Zingales, L., 2013. How pervasive is corporate fraud?, Working Paper (Feb. 2013)

Engel, E., R. Hayes, and X. Wang, 2007, “The Sarbanes Oxley Act and firms’ going private decisions,” Journal of Accounting and Economics 44, 116-145.

Feinstein, Jonathan S., 1990, Detection controlled estimation, Journal of Law and Economics, vol. 33-1, pp. 233-276.

Feng, M., Li, C., McVay, S., 2009. Internal control and management guidance. Journal of Accounting \& Economics 48 (2-3), 190-209.

FERF 2005, Financial Executives International and Financial Executives Research Foundation, Special Survey on Sarbanes-Oxley Section 404 Implementation. Morristown, N.J. (2005).

Ferola, P., 2007, The role of audit committees in the wake of corporate federalism: Sarbanes-Oxley's creep into state corporate law, Journal of Business and Securities Law, Vol. 7, pp. 143-60.

Files R., and U. Gurun, 2011, Lenders’ Response to Restatements Along the Supply Chain 20 (Oct. 1, 2011), Working Paper, available at http://ssrn.com/abstract=1636862

Freshman, A., 2012, Financial disaster as a risk factor for posttraumatic stress disorder: internet survey of trauma in victims of the Madoff Ponzi scheme, Health and Social Work, doi: 10.1093/hsw/his002. 
GAO, 2013. United States Government Accountability Office, Report to Congressional Committees, Internal Controls: SEC Should Consider Requiring Companies to Disclose Whether They Obtained an Auditor Attestation (GAO-13-582) (July 2013).

Gao, F., J. Wu, and J. Zimmerman, 2009, "Unintended consequences of granting small firms exemptions from securities regulation: evidence from the Sarbanes-Oxley Act," Journal of Accounting Research 47, 459-506

Gao. Y., 2011. The Sarbanes-Oxley Act and the choice of bond market by foreign firms, Journal of Accounting Research 49 (4), 933-968.

Gao, X., J. R. Ritter., and Z. Zhu., 2013. Where Have All the IPOs Gone? Available at SSRN: http://ssrn.com/abstract $=1954788$

Giannetti, M., and Tracy Yue Wang. 2013. Corporate Scandals and Household Stock Market Participation. Available at SSRN: http://ssrn.com/abstract=2331588

Gleason, C. A., N. T. Jenkins, and W. B. Johnson, 2008, The contagion effects of accounting restatements. Accounting Review, 83, 83-110.

Graham, C., R. Litan and S. Sukhtankar, 2002, The bigger they are, the harder they fall: an estimate of the costs of the crisis in corporate governance, Brookings Institution Working Paper (Aug. 30, 2002)

Greenspan, A., 2003. Testimony before the Committee on Financial Services. US House of Representatives, July 15, 2003.

Griffin, P.A. and D.H. Lont. 2005. Taking the Oath: Investor Response to SEC Certification under Sarbanes-Oxley, Journal of Contemporary Accounting and Economics 1, (2005) 27-63.

Griffin, P.A. and D. H. Lont. 2007. An analysis of the audit fees following the passage of Sarbanes-Oxley. Asia Pacific Journal of Accounting and Economics 14 (2): 161-192.

Guiso, L., P. Sapienza and L. Zingales, 2007, Trust the stock market, Working Paper (May 2007).

Guttentag, M., C. Porth and S. Fraidin, Brandeis’ policeman: results from a laboratory experiment on how to prevent corporate fraud, Journal of Empirical Legal Studies, v. 5, pp. 239-273.

Haldane, A., 2010, The $\$ 100$ billion question, Bank of England Executive Director of Financial Stability, Speech (March 2010). 
Hammersley, J., L. Myers, and C. Shakespeare. 2008. Market reactions to the disclosure of internal control weakness and to the characteristics of those weaknesses under section 302 of the Sarbanes Oxley Act of 2002. Review of Accounting Studies 13 (1): $141-65$.

Hennes, K. M., A. J. Leone, and B. P. Miller. 2008 The Importance of Distinguishing Errors from Irregularities in Restatement Research: The Case of Restatements and CEO/CFO Turnover. The Accounting Review: November, Vol. 83, No. 6, pp. 14871519.

Hermalin, B. E. and Weisbach, M. S., 2006. A Framework for Assessing Corporate Governance Reform. Available at SSRN: http://ssrn.com/abstract=881581.

Hertzberg, Andrew, 2005, Managerial incentives, misreporting, and the timing of social learning: A theory of slow booms and rapid recessions, Working Paper.

Hochberg, Y., P. Sapienza, and A. Vissing-Jorgensen, 2009, “A lobbying approach to evaluating the Sarbanes-Oxley Act of 2002,” Journal of Accounting Research 47, 519-583.

Hoehn, J., M. Berger and G. Blomquist, 1987, A hedonic model of interregional wages, rents and amenity values, Journal of Regional Science, vol. 27(4), pp. 605-620.

Hostak, P., E. Karaoglu., T. Lys., and G. Yang., 2013. An Examination of the Impact of the Sarbanes-Oxley Act on the Attractiveness of US Capital Markets for Foreign Firms (October 30, 2009). Review of Accounting Studies, June, Volume 18, Issue 2, pp 522-559.

Iliev, P., 2010, "The effect of SOX section 404: costs, earnings quality, and stock prices," Journal of Finance 45, 1163-1196.

Jain, P. and Z. Rezaee, 2006, "The Sarbanes-Oxley Act of 2002 and capital-market behavior: early evidence,” Contemporary Accounting Research 23, 629-654.

Jain, P. and Kim, J. and Rezaee, Z., 2008. The Sarbanes-Oxley Act of 2002 and Market Liquidity. Financial Review, Vol. 43, Issue 3, pp. 361-382, August.

Jiang, J., K. Petroni, and I. Wang. 2010. CEOs and CFOs: Who have more influence on earnings management?. Journal of Financial Economics 96 (3): 513-526.

Jin, J., K. Kanagaretnam and G. Lobo, 2011, Ability of accounting and audit quality variables to predict banking failure during the financial crisis, Journal of Banking and Finance, v. 35, pp. 2811-2819. 
Johnson, J., and J. Madura, 2009. The pricing of IPOs post-Sarbanes-Oxley. Financial Review 44, 291-310,

Johnson, S., H. Ryan and Y. Tian, 2009, Managerial incentives and corporate fraud: the sources of incentives matter, Review of Finance, vol. 13, pp. 115-145.

Johnstone, K., C. Li, and K. Rupley, 2011. “Changes in Corporate Governance Associated with the Revelation of Internal Control Material Weaknesses and their Subsequent Remediation.” Contemporary Accounting Research, 28 (1): 331-383.

Jones, R., 2004, Rethinking corporate federalism in the era of corporate reform, Journal of Corporate Law, Vol. 29, pp. 625-63.

Kahan, M. and E. B. Rock., 2011. The Insignificance of Proxy Access. Virginia Law Review, Vol. 97, pp. 1347.

Kamar, E., P. Karaca-Mandic and E. Talley, 2009, Going-private decisions and the Sarbanes-Oxley Act of 2002: a cross-country analysis, Journal of Law, Economics and Organization, v. 25, pp. 107-33.

Kang, Q., Q. Liu, and Q. Rong. 2010. The Sarbanes-Oxley Act and Corporate Investment: A Structural Assessment. Journal of Financial Economics 96: 291-305.

Karpoff, J., D. Lee and G. Martin, 2008a, The costs to firms of cooking the books, Journal of Financial and Quantitative Analysis, v. 43, pp. 581-612.

Karpoff, J., D. Lee and G. Martin, 2008b, The consequences to managers for financial misrepresentation, Journal of Financial Economics, v. 88, pp. 193-215.

Kedia, S. and T. Phillippon, 2009, The economics of fraudulent accounting, Review of Financial Studies, v. 22 pp. 2169-98.

Kedia, S. and S. Rajgopal. 2011. Do the SEC's Enforcement Preferences Affect Corporate Misconduct?,” Journal of Accounting and Economics, 51(3): 257-278.

Kedia, Simi., K. Koh., S. Rajgopal. 2013. "Evidence on Contagion in Corporate Misconduct,” working paper, Goizueta Business School, Emory University, Atlanta, GA.

Khanna, V., E.H. Kim and Y. Lu, 2013. CEO Connectedness and Corporate Frauds, Working Paper, available at http://ssrn.com/abstract=2323251.

Kim, Jeong-Bon and Song, Byron Y. and Zhang, Liandong, 2011. Internal Control Weakness and Bank Loan Contracting: Evidence from SOX section 404 Disclosures. The Accounting Review, Vol. 86, No. 4, pp. 1157-1188. 
Kim, E. Han and Lu, Yao. 2013. Corporate Governance Reforms Around the World and Cross-Border Acquisitions. Journal of Corporate Finance, 22, 236-253.

Kinney, W. R., Z.-V. Palmrose, and S. Scholz. 2004. Auditor Independence, Non-Audit Services, and Restatements: Was the US Government Right? Journal of Accounting Research 42 (3):561-588.

Klein, A., 2002a. Audit committee, board of director characteristics, and earnings management. Journal of Accounting and Economics 33, 375-400.

Koh, K., Matsumoto,D., Rajgopal,S.,2008.Meeting or beating analyst expectations in the post-scandals world: changes in stock market rewards and managerial actions. Contemporary Accounting Research 25, 1067-1098.

Koh K., S. Rajgopal., and S. Srinivasan. 2013. Non-Audit Services and Financial Reporting Quality: Evidence from 1978-1980. Review of Accounting Studies, 18, 133.

Langevoort, D., 2007, The social construction of Sarbanes-Oxley, Michigan Law Review, Vol. 105, pp. 1817-55.

Lennox, C., Pittman, J., 2010. Auditing the auditors: Evidence on the recent reforms to the external monitoring of audit firms. Journal of Accounting and Economics 49, 84103

Leuz, C., A. Triantis, and T. Wang, 2008, "Why do firms go dark? Causes and economic consequences of voluntary SEC deregistrations,” Journal of Accounting and Economics 45, 181-208.

Leuz, C., 2007, Was the Sarbanes-Oxley Act of 2002 really this costly? A discussion of evidence from event returns and going-private decisions, Journal of Accounting and Economics 44, 146-165.

Lev, B., 2003, Corporate earnings: facts and fiction, Journal of Economic Perspectives, v. 17 , pp. 27-50.

Li, S., 2013, Corporate financial fraud: an application of detection controlled estimation, Working Paper (July 2013).

Li, H., M. Pincus, and S. Rego, 2008, "Market reaction to events surrounding the Sarbanes-Oxley Act of 2002,” Journal of Law and Economics 51, 111-134

Li, C., L. Sun, and M. Ettredge. 2010. "Financial Executive Qualifications, Financial Executive Turnover, and Adverse SOX 404 Opinions.” Journal of Accounting and Economics 50: 93-110. 
Linck, J.S., J. M. Netter and T. Yang. 2009. The effects and unintended consequences of the Sarbanes-Oxley Act on the supply and demand for directors. Review of Financial Studies (August) 22 (8): 3287-3328.

Litvak, K., 2007, "The effect of the Sarbanes-Oxley act on non-US companies crosslisted in the US,” Journal of Corporate Finance 13, 195-228

Lobo, G., and J. Zhou. 2006. Did conservatism in financial reporting increase after the Sarbanes-Oxley Act? Initial evidence. Accounting Horizons 20 (1): 57-73.

Loughran, T. and J. R. Ritter, 1995, The new issues puzzle, Journal of Finance 50, 23-52

Ludwig, J., 2006, Testimony before United States Senate Committee on the Judiciary (Sep. 19, 2006).

Ludwig, J., 2010, The costs of crime, Criminology and Public Policy, v. 9, pp. 307-11.

Manzi, J., 2012., Uncontrolled: the surprising payoff of trial-and-error for business, politics, and society. Basic Books, Philadelphia, PA.

Marosi, A., \& N. Massoud., 2008, You can enter but you cannot leave... - US securities markets and foreign firms. Journal of Finance, 63, 2477-2506.

Michaels, A., 2003. After a year of US corporate clean-up, William Donaldson calls for a return to risk-taking. FinancialTimes.com, July 24, 2003.

Mitchell, K., et al., 2011. IPO Task Force, Rebuilding the IPO On-Ramp: Putting Emerging Companies and the Job Market Back to the Road on Growth (Oct. 20, 2011).

Moore, S. and J. Shepherd, 2006, The cost of fear: shadow pricing the intangible costs of crime, Applied Economics, v. 38, pp. 293-300.

Nagin D., A. Piquero, E. Scott, and L. Steinberg, 2006, Public preferences for rehabilitation versus incarceration of juvenile offenders: evidence from a contingent valuation survey, Criminal Public Policy, v.5, pp. 627-652.

Owens, Edward L. and Wu, Joanna, 2012. Window Dressing of Short-Term Borrowings. Simon School Working Paper No. FR 11-15. Available at SSRN: $\underline{\text { http://ssrn.com/abstract }=1811110}$

Picard, I. 2013, Trustee's Ninth Interim Report for the Period Ended March 31, 2012, In re Bernard L. Madoff, United States Bankruptcy Court, Southern District of New York (April 30, 2013). 
Piotroski, J.D. and S. Srinivasan. 2008. Regulation and bonding: The Sarbanes-Oxley act and the flow of international listings. Journal of Accounting Research (May) 46 (2): 383-425.

Plumlee M., and Teri Lombardi Yohn., 2010. An analysis of underlying causes attributed to restatements. Accounting Horizons, v. 24:1, pp. 41-64.

Posner, E. and G. Weyl, 2013, Benefit-cost analysis for financial regulation, American Economic Review, v. 103, pp. 1-5

Povel, P., R. Singh, and A. Winton, 2007, Booms, busts, and fraud, Review of Financial Studies, v. 20, pp. 1219-1254.

Qian, Jun “QJ”, P. E. Strahan and J.L. Zhu, The Economic Benefits of the SarbanesOxley Act? Evidence from a Natural Experiment, Working Paper (Dec. 2009), available at http://fic.wharton.upenn.edu/fic/papers/09/0941.pdf

Raghunandan, K., Rama, D.V., 2006. SOX Section 404 material weakness disclosures and audit fees. Auditing: A Journal of Practice and Theory 25(1), 99-114.

Reifschneider, D., R. Tetlow, and J. Williams, 1999, Aggregate Disturbances, Monetary Policy, and the Macroeconomy: The FRB/US Perspective, Fed. Res. Bull. 1-19

Rice, S., and D. Weber. 2012, How effective is internal control reporting under SOX 404 ? Determinants of the (non-)disclosure of existing material weaknesses, Journal of Accounting Research, v. 50 (3), pp. 811-843.

Rice, S., D. Weber., and B. Wu., 2013. Does SOX 404 have teeth? Consequences of the failure to report existing internal control weaknesses, available at SSRN: http://ssrn.com/abstract=2239965

Roe, M., 2009, Delaware and Washington as corporate lawmakers, Delaware Journal of Corporate Law, v. 34, pp. 1-33.

Romano, R., 2005. “The Sarbanes-Oxley Act and the Making of Quack Corporate Governance.” Yale Law Journal, 114(7): 1521-1161.

Ryan, Ellen M., and Laura E. Simmons. 2012. "Securities Class Action Settlements 2012 Review and Analysis.” Cornerstone Research.

SEC 2004. US Securities and Exchange Commission, Management's Report on Internal Control Over Financial Reporting and Certification of Disclosure in Exchange Act Periodic Reports, 69 Fed. Reg. 9,722 (Mar. 1, 2004). 
SEC 2009. US Securities and Exchange Commission. Study and Recommendations on Sections 404(b) of the Sarbanes-Oxley Act of 2002 For Issuers with Public Float Between \$75 and \$250 Million. Washington, D.C.: 2011.

SEC 2011. US Securities and Exchange Commission. Study of the Sarbanes-Oxley Act of 2002 Section 404 Internal Control over Financial Reporting Requirements. Washington, D.C.: 2009.

Scholz, S. 2008. The changing nature and consequences of public company financial restatements:1997-2006. The U. S. Department of the Treasury. Available at: http://www.treasury.gov/press-center/pressreleases/Documents/FinancialRestatements19972006.pdf.

Shavell, Steven M. 1986. "The Judgment Proof Problem," 6 International Review of Law and Economics 45.

Shleifer, A. and R. Vishny, 2003, Stock market driven acquisitions, Journal of Financial Economics, v. 70, pp. 295-311.

Sikka, P. 2009, Financial crisis and the silence of the auditors, Accounting, Organizations and Society, v. 34, pp. 868-873.

Srinivasan, Suraj and A. Wahid, and G. Yu,. 2013 Admitting Mistakes: Home Country Effect on the Reliability of Restatement Reporting Available at SSRN: http://ssrn.com/abstract=2065892

Szewczyk, S. H., and G. P. Tsetsekos, 1992, State intervention in the market for corporate control: The case of Pennsylvania Senate Bill 1310, Journal of Financial Economics 31, 3-23.

Thaler, Richard. 1978. "A Note on the Value of Crime Control: Evidence from the Property Market.” Journal of Urban Economics 5(1): 137-145.

Valukas, A., 2010, Report, In re Lehman Brothers Holdings, Inc., United States Bankruptcy Court, Southern District of New York, volume I (Mar. 11, 2010).

Van de Poel, K. and A. Vanstraelen. 2011. Management reporting on internal control and earnings quality: Insights from a 'comply-or-explain' internal control. Auditing: A Journal of Practice and Theory, 30(3): 181-209.

Velikonja, U. 2013. The Costs of Securities Fraud, Wm. \& Mary L. Rev. vol. 54, pp, .1887-1957.

Viscusi, K., 2000, The Value of Life in Legal Context: Survey and Critique, American Law and Economics Review, v. 2, pp. 195-222. 
Vogel, G., 2009, Despite initial fears to the contrary, it appears that Sarbanes-Oxley gave private litigants a "dull sword" when it comes to piercing the corporate veil, 14 Fordham Journal of Corporate and Financial Law, Vo. 14, pp. 415-442.

Wang, X., 2013. Corporate securities fraud: Insights from a new empirical framework Journal of Law, Economics and Organization, vol. 29, issue 3, pages 535-568

Wang, X., 2010, “Increased disclosure requirements and corporate governance decisions: evidence from Chief Financial Officers in the pre- and post-Sarbanes Oxley periods," Journal of Accounting Research 48, 885-920.

Wang, T., A.Winton and X. Yu, 2010, Corporate fraud and business conditions: evidence from IPOs, Journal of Finance, v. 65, pp. 2255-2292.

Weiss, A. and G. Birkner, 2008, Charities, day schools hard hit by Madoff scandal, Forward.com (Dec. 17, 2008).

Whalen, D., C. McCoy and P. Cross, 2013. Audit Fees and Non-Audit Fees: An Eleven Year Trend. Audit Analytics.

Woo, C., 2011, United States securities regulation and foreign private issuers: lessons from the Sarbanes-Oxley Act, 48 American Business Law Journal, Vol. 48, pp. 11976.

Yeh, Y., H. Chung and C-L. Liu, Committee independence and financial institution performance during the 2007-08 credit crunch: evidence from a multi-country study, Corporate Governance: An International Review, v. 19(5), pp. 437-458.

Zakolyukina, A., 2013, Measuring intentional manipulation: a structural approach, Working Paper (Mar. 30, 2103).

Zhang, I., 2007, “Economic consequences of the Sarbanes Oxley Act of 2002,” Journal of Accounting and Economics 44, 74-115. 


\section{Figure 1: PCAOB and SEC Budgets}

Panel A: The figure shows the level of PCAOB budget over time (Bars) and the growth in PCAOB budget relative to the SEC budget

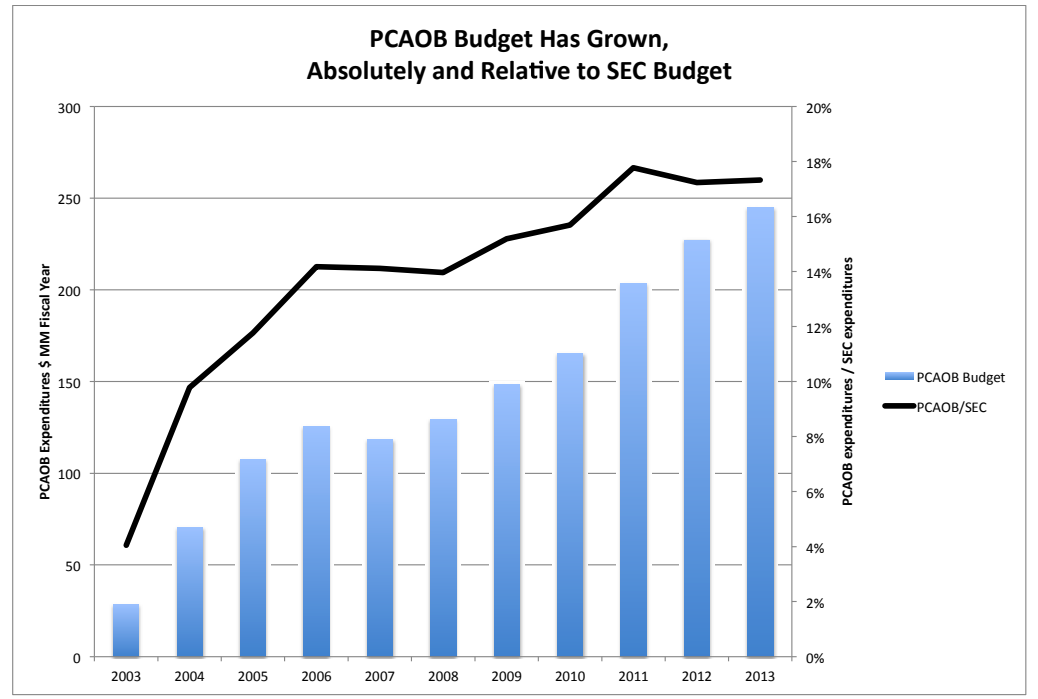

Panel B: The figure shows the level of the SEC budget over time. The Y-axis is in dollar million.

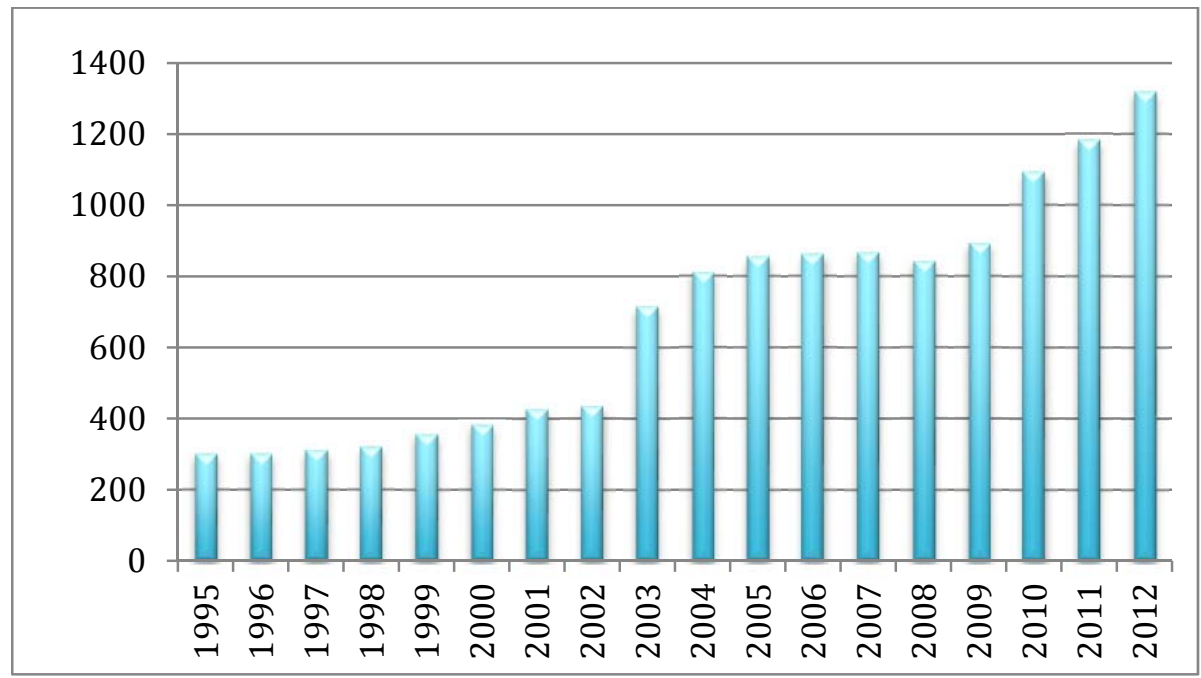


Figure 2: Frequency of US firms going private and going dark.

The figure shows the rate of US firms going private (blue line) and going dark (red line). Going private numbers are from Engel, Hayes, and Wang (2007). Going Dark data are from Leuz, Triantis and Wang (2008).

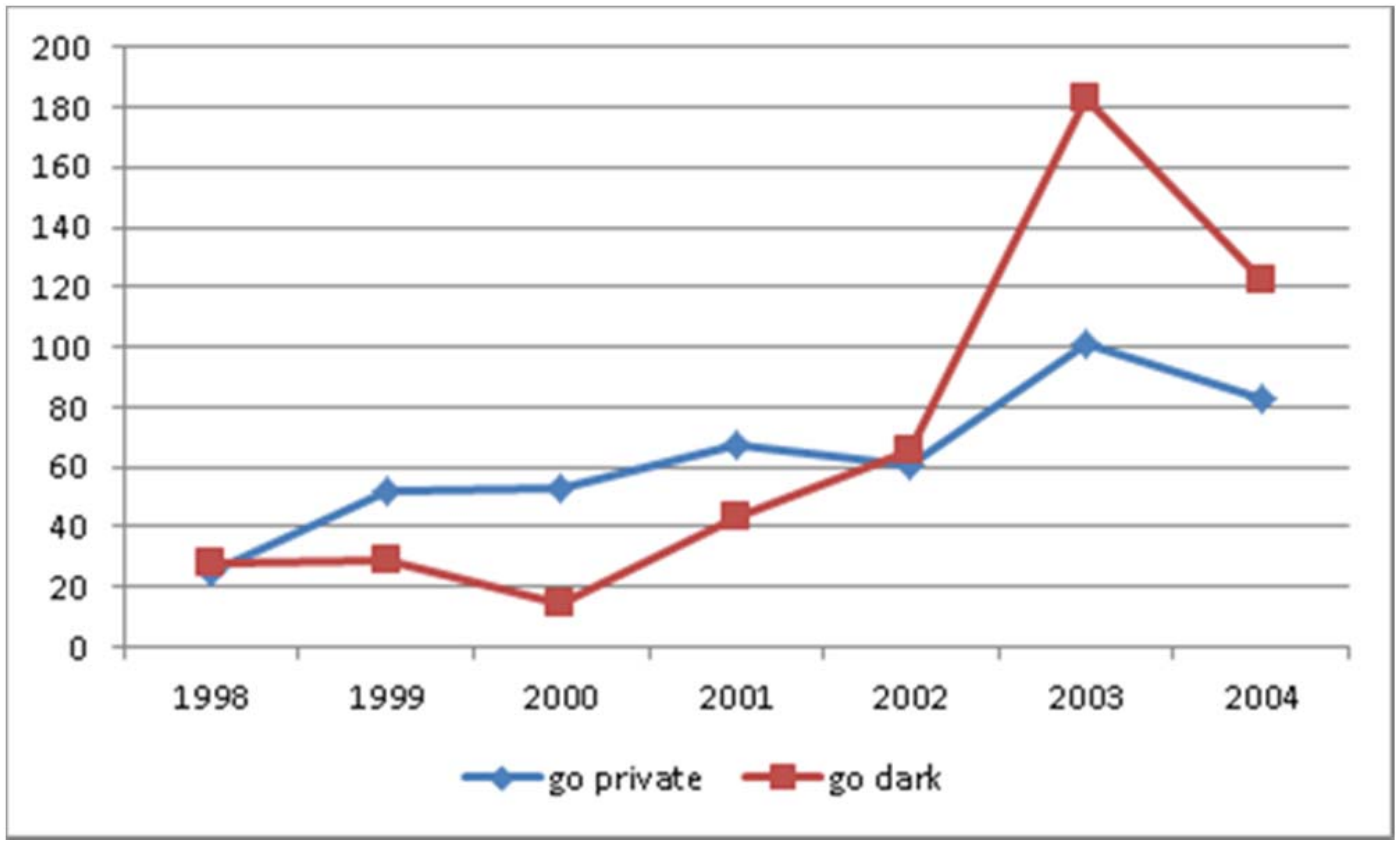




\section{Figure 3 Number of IPOs in the US}

The figure shows the frequency of IPOs in the U.S. by small ( $<\$ 50 \mathrm{MM}$ sales) and large firms, by year. The figure is from Gao et al (2013).

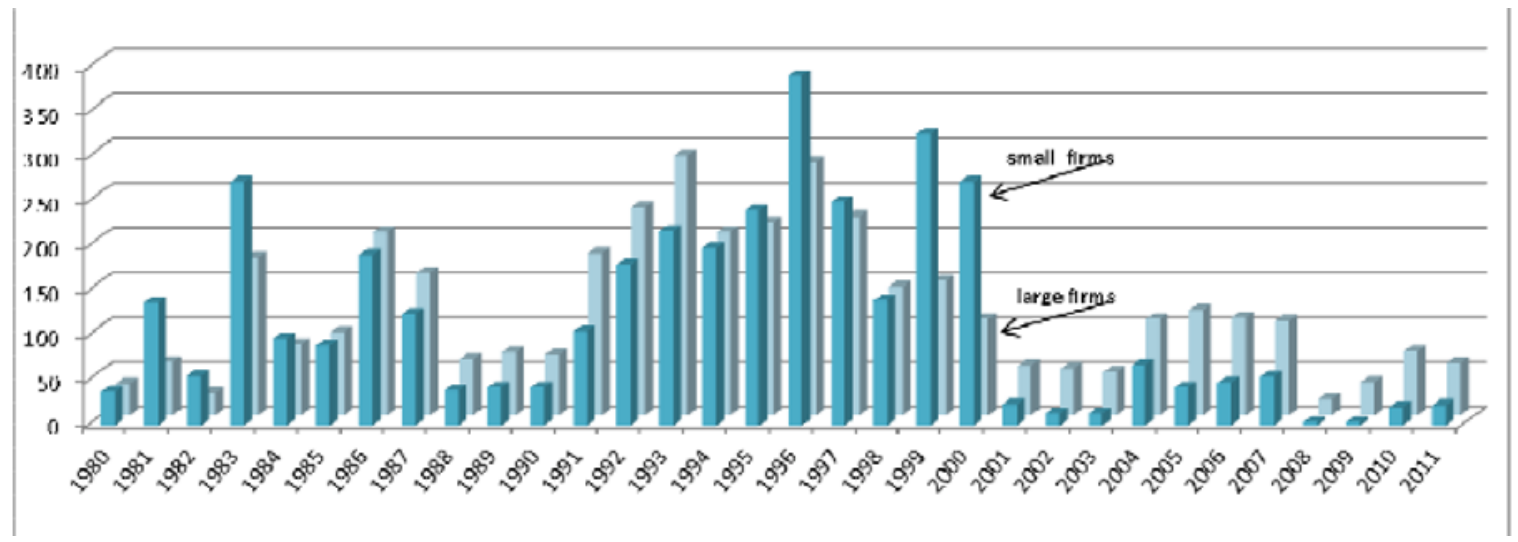


Figure 4: Frequency of foreign firms listing and delisting from US exchanges.

The figure shows thee number of foreign firms listing in the US over time (red line) and the number of foreign firms delisting from the U.S. over time (green line). Data from new listings are from Piotroski and Srinivasan (2008) and for delistings are from Hostak et al (2013).

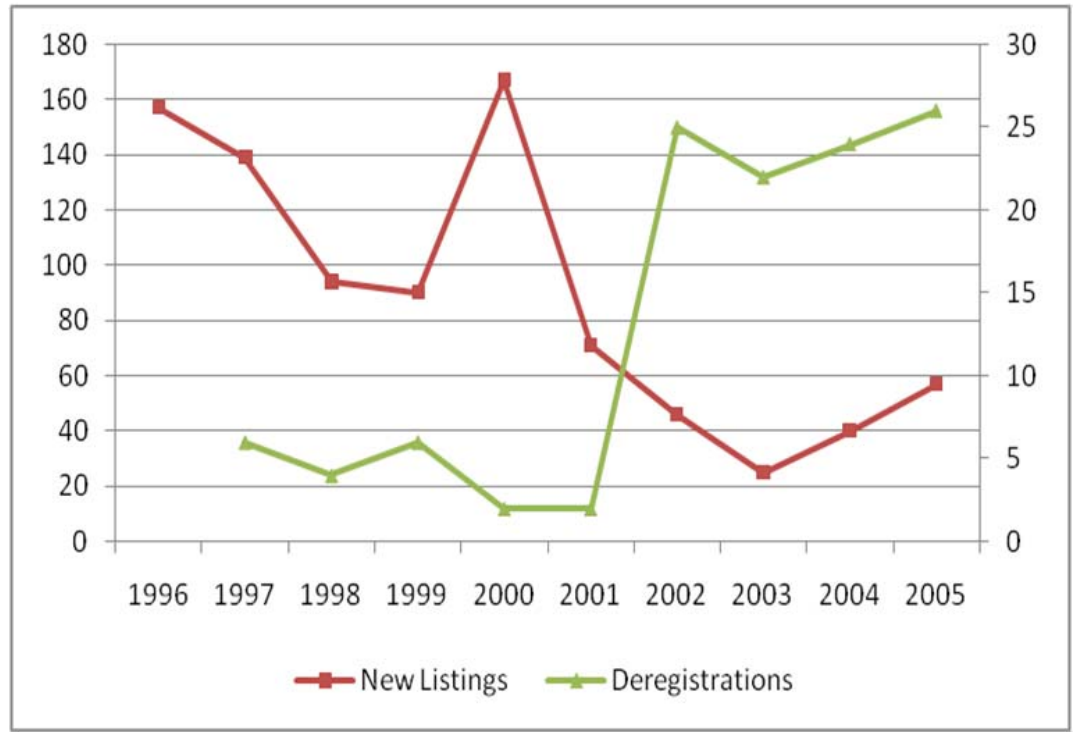


Figure 5: Share of Public Firm market Capitalization in Iliev 2010

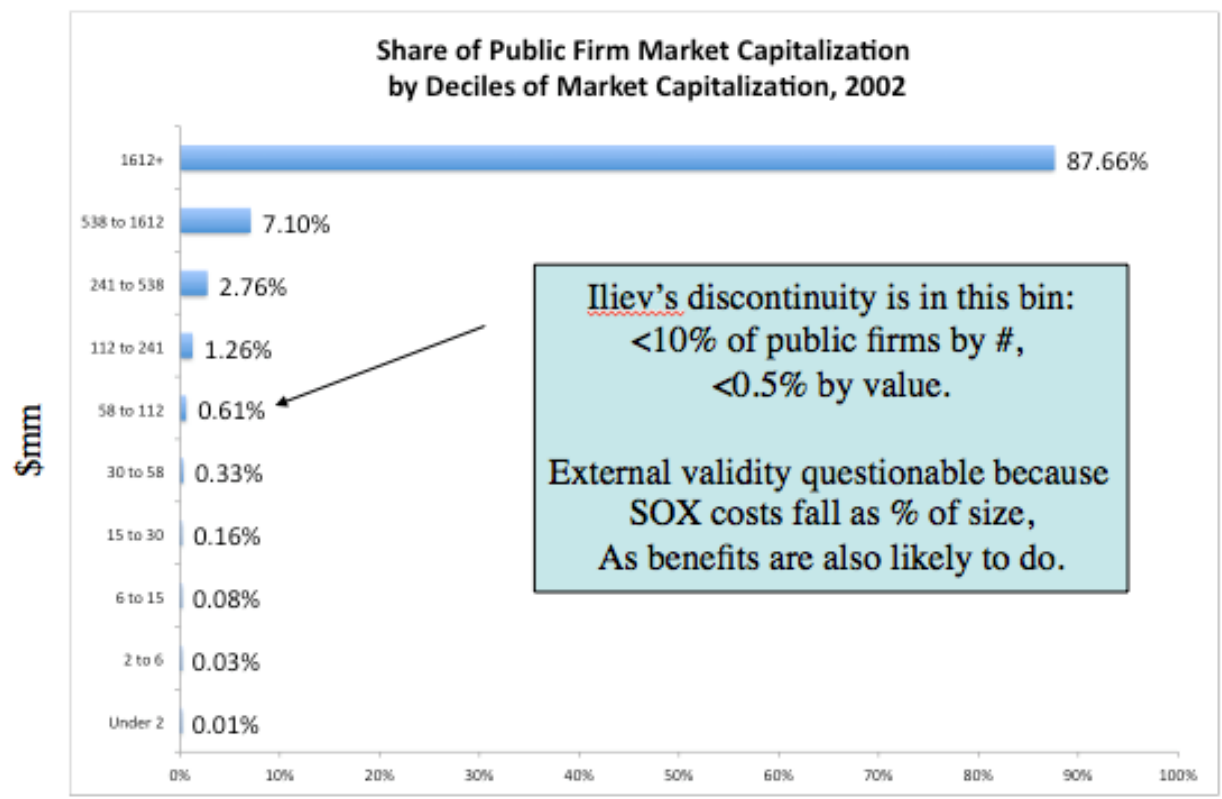


Figure 6 Securities litigation before and after SOX

Panel A: The figure shows litigation rate for US firms (red line) and litigation rate for independent directors on the board of US firms (green line). The graph is from Brochet and Srinivasan (2013).

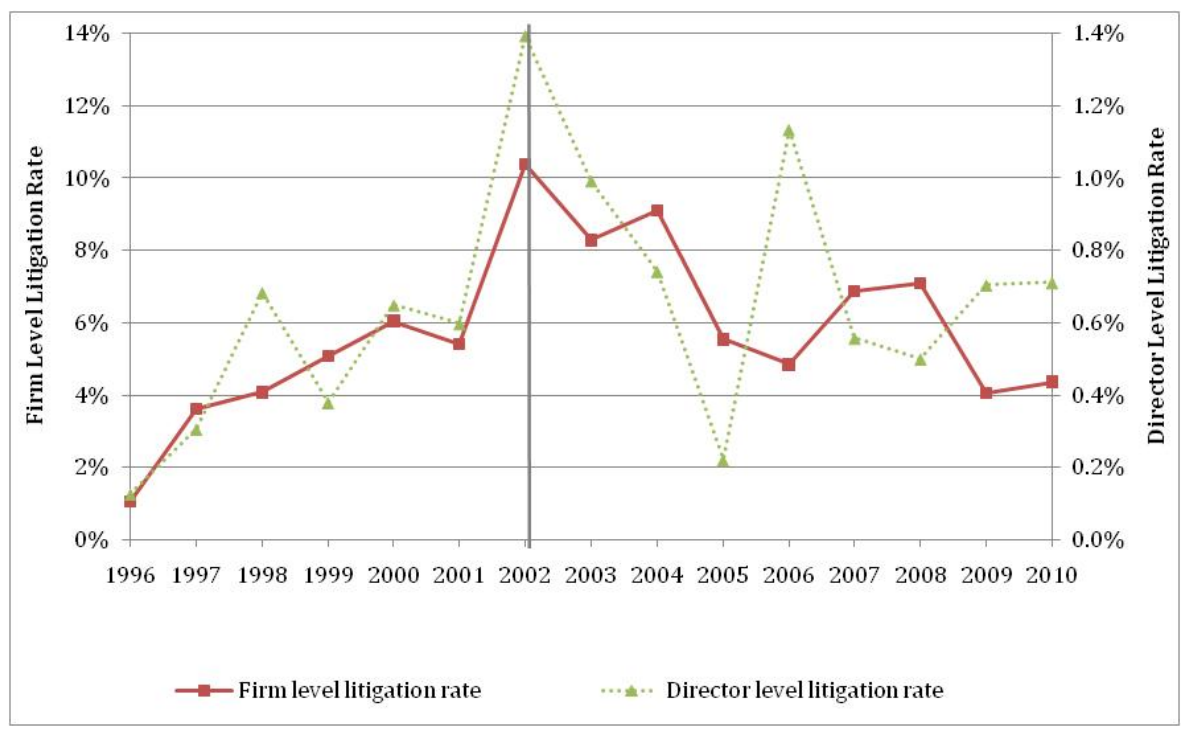

Panel B: The figure shows total settlement amounts in securities class actions between 2003 and 2012 in \$ million. The figure is from Ryan and Simmons (2012).

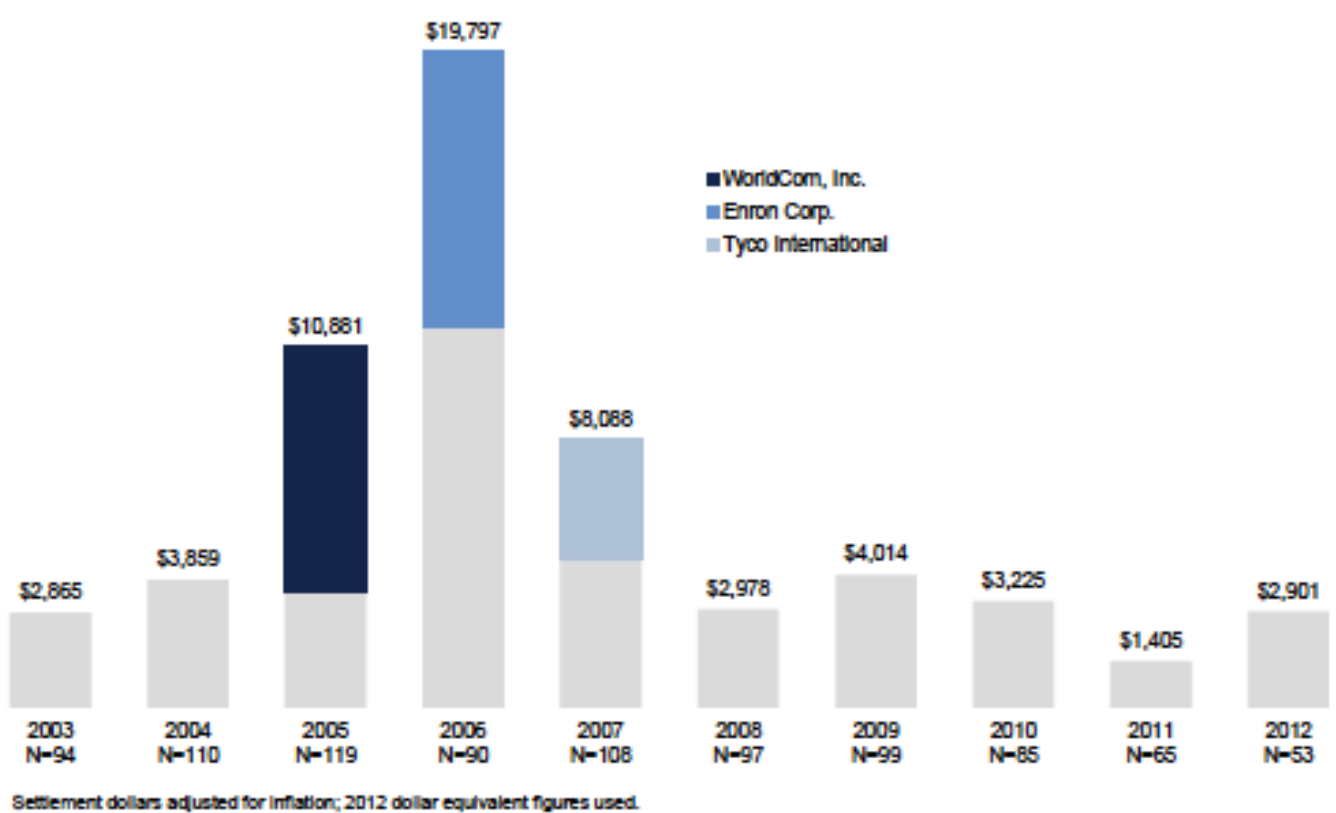




\section{Figure 7. Risk taking and investments}

The figure is from Albuquerque and Zhu (2013). Panel A presents capital expenditure scaled by total assets. Panel B presents R\&D expenditure scaled by total assets. Panel C presents Cash holdings scaled by total assets and Panel D presents standard deviation of returns.

Panel A: Capital expenditure scaled by total assets

Panel B: R\&D expenditure scaled by total assets

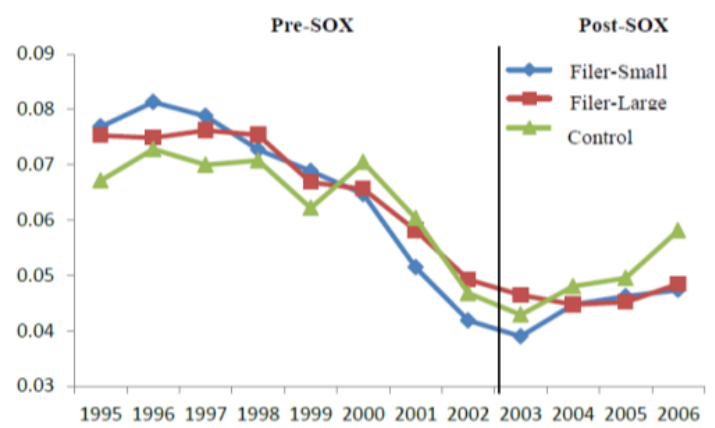

Panel C: Cash holdings scaled by total assets

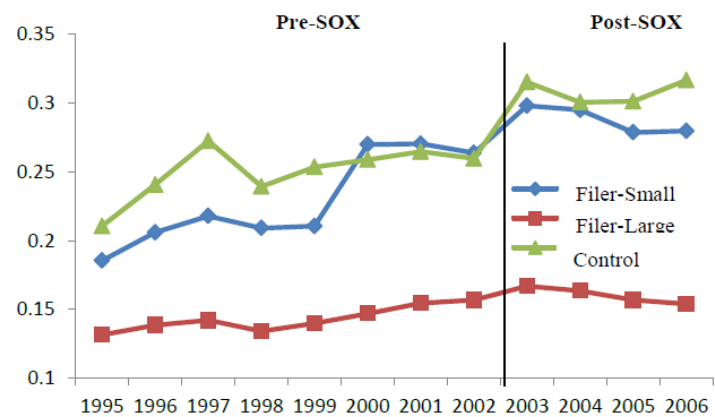

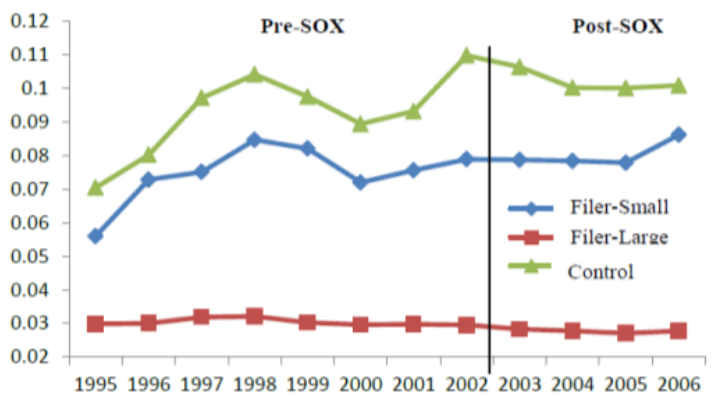

Panel D: Standard deviation of returns

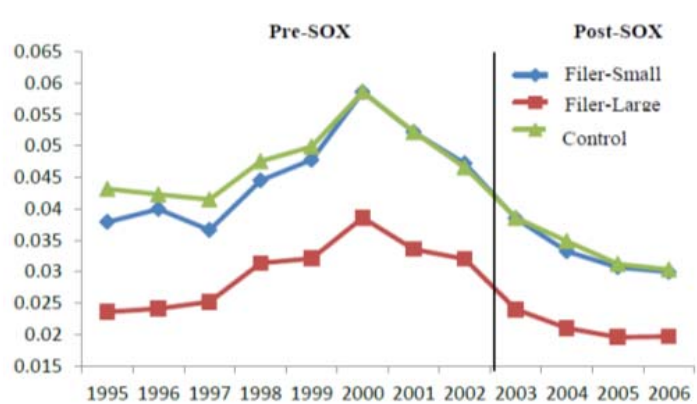




\section{Figure 8 Restatements and SOX 404 adverse reports}

Panel A: The figure presents the time series of reported restatements. Sued restatements represent restatements that are followed by a securities class action lawsuit thereby indicating a greater severity of the restatement compared to restatements that are not followed by a lawsuit. All restatements include sued and non-sued restatements. Data are from Audit Analytics, Srinivasan, Wahid and Yu (2013) and Cheng, Srinivasan and Yu (2013).

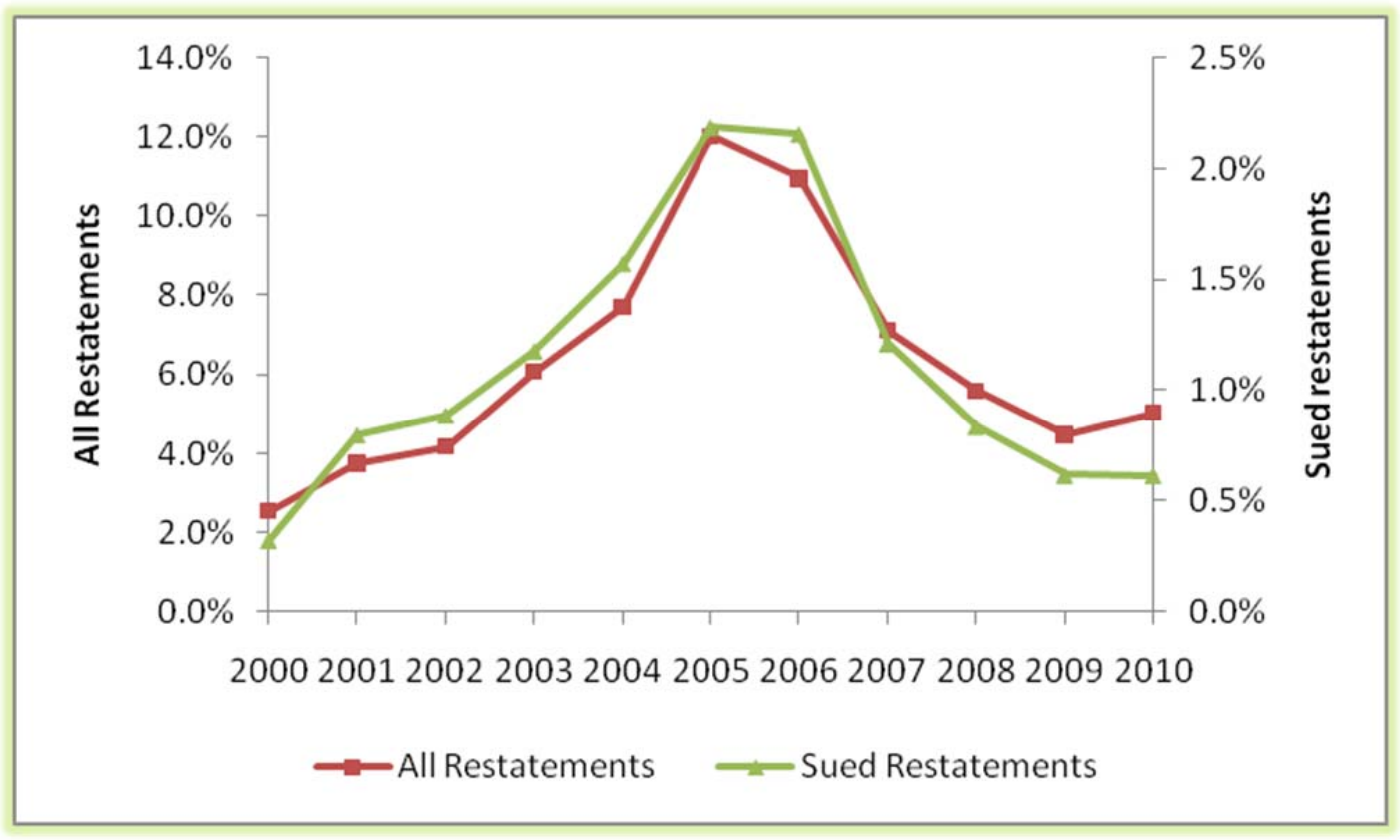

Panel B: The figure presents the percentage of firms receiving adverse Sec 404 auditor attestations of internal control weaknesses as a proportion of all companies. Data are from Audit Analytics. 


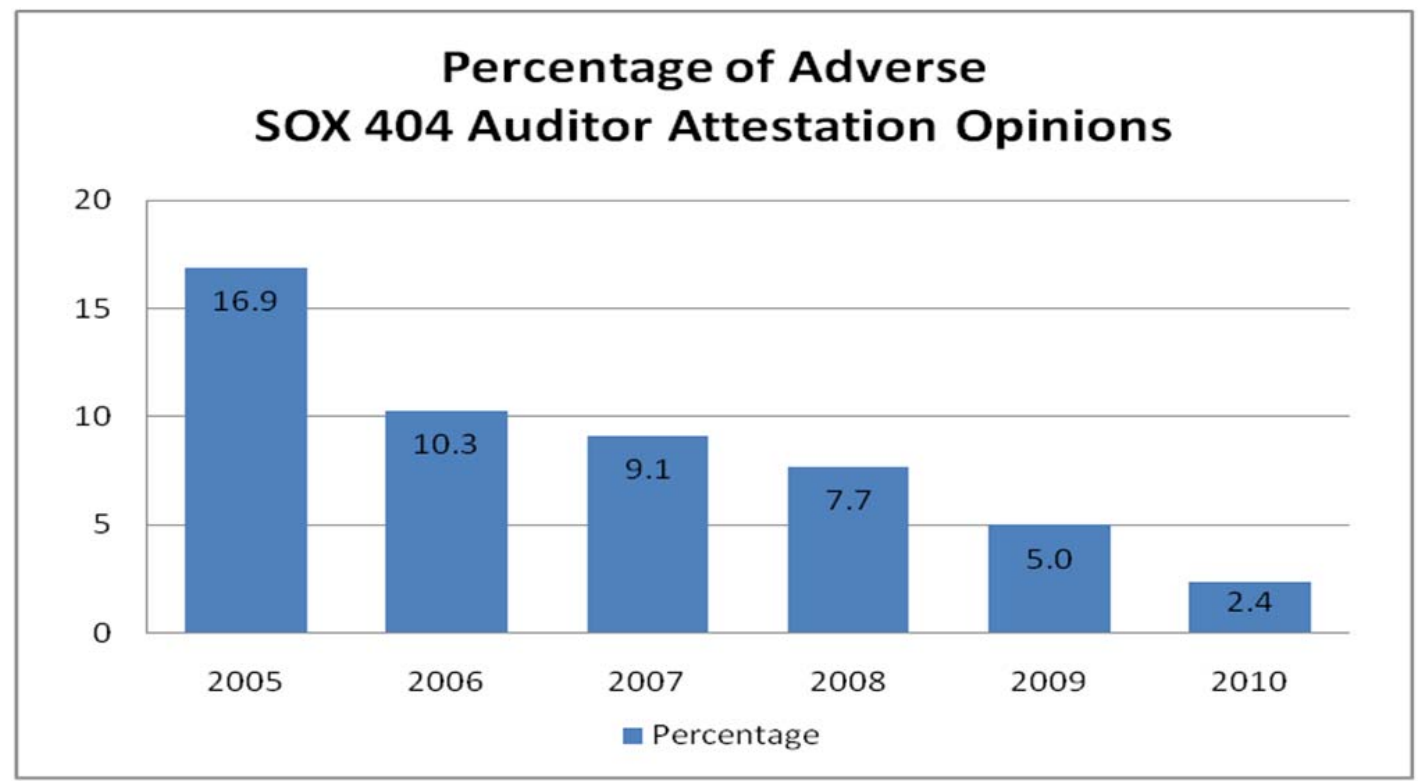




\section{Table $1 \quad$ SEC Enforcement Actions}

The table provides descriptive statistics on accounting and auditing enforcement actions (AAER) by the SEC over time. Median Asset refers to the median total asset of the firms for which an AAER was issued in that particular year. Data used for this table as the same as in Dechow, Ge, Larson and Sloan (2011) and were generously provided by Patricia Dechow.

\begin{tabular}{|l|c|c|}
\hline Year & Number of AAERs & $\begin{array}{l}\text { Median Asset } \\
\text { \$ MM }\end{array}$ \\
\hline 1995 & 35 & 32.3 \\
\hline 1996 & 40 & 16.8 \\
\hline 1997 & 41 & 36.8 \\
\hline 1998 & 17 & 64.2 \\
\hline 1999 & 32 & 73.8 \\
\hline 2000 & 44 & 79.0 \\
\hline 2001 & 28 & 101.4 \\
\hline 2002 & 60 & 163.9 \\
\hline 2003 & 55 & 143.0 \\
\hline 2004 & 59 & 526.3 \\
\hline 2005 & 44 & 785.0 \\
\hline 2006 & 47 & 717.2 \\
\hline 2007 & 46 & 1967.2 \\
\hline 2008 & 27 & 1833.8 \\
\hline 2009 & 47 & 543.1 \\
\hline
\end{tabular}

